\title{
ValpoScholar
}

Valparaiso University Law Review

Volume 41

Number 2 Winter 2007

pp.697-154

Winter 2007

\section{"The Interest of the Man": James Madison, Popular Constitutionalism, and the Theory of Deliberative Democracy}

Larry D. Kramer

Follow this and additional works at: https://scholar.valpo.edu/vulr

Part of the Law Commons

\section{Recommended Citation}

Larry D. Kramer, "The Interest of the Man": James Madison, Popular Constitutionalism, and the Theory of Deliberative Democracy, 41 Val. U. L. Rev. 697 (2007).

Available at: https://scholar.valpo.edu/vulr/vol41/iss2/5

This Seegers Lecture is brought to you for free and open access by the Valparaiso University Law School at ValpoScholar. It has been accepted for inclusion in Valparaiso University Law Review by an authorized administrator of ValpoScholar. For more information, please contact a ValpoScholar staff member at scholar@valpo.edu. 


\title{
Lectures
}

\section{"THE INTEREST OF THE MAN": JAMES MADISON, POPULAR CONSTITUTIONALISM, AND THE THEORY OF DELIBERATIVE DEMOCRACY}

\begin{abstract}
Larry D. Kramer*
In 2004, I published a book titled The People Themselves that recounted the origins and early history of judicial review. ${ }^{1}$ It had several objectives, some historical, others normative. From a historical perspective, my chief aim was to question and hopefully to dispel certain myths about the Founding. In particular, I wanted to counter the idea that our Constitution was, first and foremost, an instrument of reaction designed to blunt democratic politics by channeling authority to an elite removed as far as possible from popular control. This widely held belief caricatures a more complicated story that is also more democratic in its overtones. Along the way, I hoped to raise some questions about our willingness today to cede control over the Constitution to the judiciary, a development more recent than most people believe and one that derives considerable support from this misreading of our history.

Today, we have for all practical purposes turned the Constitution over to the Supreme Court. We take for granted that final interpretive authority rests with the Justices. Yes, the other branches and departments have a role. Yes, they must interpret the Constitution in deciding what they can and cannot do (which they then indicate by acting or declining to act on constitutional grounds or for constitutional reasons). But when disputes arise, we - and by "we" I mean not just members of the legal profession, but political leaders and the American public as well-assume that the Supreme Court is responsible for their final resolution. It is the Court that tells us what the Constitution means. This, in a nutshell, is the principle of judicial supremacy.
\end{abstract}

\footnotetext{
Richard E. Lang Professor and Dean, Stanford Law School. I am grateful for comments by Josh Cohen, John Ferejohn, Barry Friedman, Tom Grey, Mike Klarman, Daryl Levinson, David Luban, Josh Ober, Robert Post, Jack Rakove, Colleen Sheehan, Mark Tushnet, Gordon Wood, and participants at the Legal Theory Workshop and the Political Theory Workshop at Stanford University.

1 LARRY D. KRAMER, THE PEOPLE THEMSELVES: POPULAR CONSTITUTIONALISM AND JUDICIAL REVIEW (2004) [hereinafter KRAMER, THE PEOPLE THEMSELVES].
} 
Valparaiso University Law Review, Vol. 41, No. 2 [2007], Art. 5

We can still disagree with the Court. No one takes supremacy to mean that once the Justices have spoken everyone must submissively lower their gaze and slink home. We can, if we choose, shriek our heads off in protest of Supreme Court rulings. But our options for changing those rulings, for establishing a different interpretation, are said to be limited to amending the text (that is, making new constitutional law), ${ }^{2}$ importuning the Justices to chart a different course, and waiting for one or more of them to die or tire of the job so we can (hopefully) appoint new Justices with views more to our liking. ${ }^{3}$ Anything else, we are told, is unlawful and unconstitutional. The court-packing, jurisdiction-stripping, budget-cutting, judgmentignoring actions of such rascally presidents as Thomas Jefferson, Andrew Jackson, Abraham Lincoln, and both Roosevelts were a betrayal of judicial independence: a threat to the very foundations of constitutional order that must never be repeated.

The modern constitutional system thus draws a distinction between interpreting an existing Constitution and making new constitutional law and does its best to confine popular control to the latter, nearly impossible task. The community at large has no formal authority to interpret. On the contrary, resisting popular views about the meaning of the Constitution is considered a judicial virtue, which is why battles over new Supreme Court appointments have grown so fierce in recent years. The stakes are indeed high once we accept that the Justices have the power to decide for us what the Constitution means, and that their decisions determine, finally, what constitutional law "is."

2 For this purpose, I do not care whether new constitutional law must be made exclusively through Article V or whether the process includes extra-textual means as well. See BRUCE ACKerman, 1 We the PeOPle: Foundations (1991); Akhil Reed Amar, The Consent of the Governed: Constitutional Amendment Outside Article V, 94 CoLUM. L. REV. 457 (1994). Whether the Constitution can be amended outside Article V has always struck me as, if not quite irrelevant, insignificant compared to the more important question of interpretive authority. It becomes a matter of consequence only once the power to interpret has been removed from popular control and lodged in courts.

3 Consider in this regard the recent legislation banning abortions enacted in South Dakota. See South Dakota Women's Health and Human Life Protection Act, H.B. 1215, 2006 Sess. (S.D. 2006). In enacting a statute blatantly at odds not just with Planned Parenthood of Se. Pa. v. Casey, 505 U.S. 833 (1992), but also with Roe v. Wade, 410 U.S. 113 (1973), South Dakota's legislators were not claiming authority to ignore the Court. They did not assert co-equal authority to say what the Constitution means and adopt legislation in the belief that they were not bound by the Court's different interpretation. Quite the opposite: they accepted judicial supremacy and were submitting themselves to the Court's superior authority. They enacted this legislation because they believe they do not have power to ignore the Court and want it to say whether Roe is still good law now that two new Justices are on the bench. They chose this route, in other words, precisely because they accept the Court's word as final on the matter. 
Constitutionalism in the Founding era was different. Then, power to interpret (and not just the power to make) constitutional law was thought to reside with the people. And not theoretically or in the abstract, but in an active, ongoing sense. It was the community at large - not the judiciary, not any branch of the government-that controlled the meaning of the Constitution and was responsible for ensuring its proper implementation in the day-to-day process of governing. This is the notion I labeled "popular constitutionalism" - to distinguish it from "legal constitutionalism" or the idea that constitutional interpretation has been turned over to the judiciary and, in particular, to the Supreme Court.

I should take a moment to clarify the way in which popular constitutionalism is not mere politics, but is in fact a legal concept that treats the Constitution as "law" in its proper sense. Both in daily parlance and as a technical matter, we draw a line between law and politics and see them as distinct categories. Twentieth-century legal scholarship may have made this line fuzzy, but we still think of law as different from politics in at least two important respects.

First, where politics is viewed as a matter of free choice or will, law is understood to contain an objective component that binds and limits. In politics, a lawmaker is free to act as he or she thinks best. Law, in contrast, is more constrained and constraining. Law interpreting, unlike legislating, is not a matter of mere will or preference, but is to some extent formally limited by the outcomes of politics. A law exists, and someone called upon to interpret and apply the law is not as free as the lawmaker to do what he or she wants. The law itself encumbers the field of available action.

Obviously, this description oversimplifies a complex relationship. There are objective constraints in politics as well as in law (though different kinds of constraints), and both law and politics involve the working out of reasons for action (though different kinds of reasons). Nevertheless, the basic distinction holds. There is, to be sure, disagreement about the extent of the constraint created by law. No one today believes that interpretation is a mechanical process without freedom of choice, but neither do we think of reading and applying law as indistinguishable from politics. Precisely where legal interpretation lies along the continuum between these extremes remains an important question in jurisprudence. It is, however, a question I have no interest in addressing here. For present purposes, what matters is simply to recognize that the debate presupposes that applying law differs 
from doing politics because it includes constraints that do not exist in the political domain.

A second ground on which law and politics are distinguished has to do with the relevant actors. Where politics is a realm of legislatures and executives and politically accountable officials, law is the realm of lawyers and judges and courts. This is not a formal principle so much as a customary, almost instinctual assumption. No one studies it or justifies or refutes it; no one tries to define it with precision or to explain the many and obvious exceptions. It is, rather, a postulate that is largely taken for granted. Just defining the Constitution as "law" was thus a big part of the reason we became comfortable assigning courts final interpretive authority over its meaning. ${ }^{4}$

Popular constitutionalism is law-like in that it accepts the first of these distinctions: that legal interpretation imposes constraints different from those that exist in politics. The Constitution remains "law" in a system of popular constitutionalism in that whoever is doing the interpreting is bound by the Constitution's legal content and must ascertain and enforce whatever limits the text imposes on political action and political actors. Where popular constitutionalism differs from present-day understandings is on the second ground. It does not assume that authoritative legal interpretation can take place only in courts, but rather supposes that an equally valid process of interpretation can be undertaken in the political branches and by the community at large. Anyone called upon to interpret the Constitution can treat it as "law." They may not always do so, but there is nothing inherent in authoritative legal interpretation that requires it to be done by members of the bar or bench.

Popular constitutionalism thus rests and relies on a political culture in which public officials, community leaders, and ordinary citizens believe in the distinction between law and politics, share a set of conventions about how to argue within each domain, and take seriously the role difference it produces. In a system of popular constitutionalism, participants respond to different arguments in each setting and treat questions of constitutional interpretation as "legal" problems that can be settled only by resort to the "law" as understood through interpretive norms like text, history, and precedent. Interests, desires, and beliefs about policy obviously matter, and ordinary citizens think about constitutional meaning in their light. But so, too, do lawyers and judges. Indeed, if anything, our professional training

4 Larry D. Kramer, The Supreme Court, 2000 Term - Foreword: We the Court, 115 HARV. L. REV. 4, 8-10 (2001). 
has made us more skeptical than lay people about the extent to which the law binds, albeit more adept at masking our cynicism in technical argument.

$* * *$

So much is straightforward. People can differ about whether it is realistic to think that ordinary citizens care about the Constitution as "law" or are even capable of doing so, whether they have the commitment, the intelligence, and the attention span to make popular constitutionalism plausible. These are empirical propositions: not easily tested, but also not hard to anticipate or argue about. I was prepared for this sort of challenge when I wrote The People Themselves, at ease with my belief that lay people do take the Constitution seriously, and comfortable arguing that, even if lawyers and judges are in some sense "better" at constitutional interpretation, that alone cannot justify anything so extreme as judicial supremacy.

Does it not seem strange, after all, to celebrate a system for its commitment to self government, meaning popular control of the government and laws, and then to turn around and say that the most important laws are just too important to be left to an ignorant mass? Jeremy Waldron has noted, rightly I think, how deeply at odds this mistrust of the capacity of ordinary citizens to think responsibly about rights is with the assumptions we make about why they are entitled to those rights in the first place (to wit, that human individuals are thinking agents "endowed with an ability to deliberate morally, to see things from others' points of view, and to transcend a preoccupation with [their] own particular or sectional interests"). ${ }^{5}$ Popular government is fine, it turns out, but only so long as we're not talking about anything too essential. Really foundational matters should be left to a more dependable oligarch. ${ }^{6}$

5 JEREMY WALDRON, LAW AND DISAGREEMENT 250 (1999).

6 Legal commentators and philosophers have been wonderfully adept at explaining how giving judges the last word on constitutional meaning is not inconsistent with democracy, which surely it is not, as a concept like "democracy" is capacious enough to include all sorts of qualifications and limitations. The objection to judicial supremacy does not depend on arguing that it cannot be reconciled with "democracy." It rests, rather, on the idea that supremacy is unnecessary: that it diminishes the scope of popular involvement for inadequate reasons. At the end of the day, all the work done to justify judicial supremacy has no better or different basis than mistrust of the larger community. It's not about majority rule, but about which majority rules; proponents of judicial supremacy simply trust a majority of nine more than they trust a majority of the larger community, at least when it comes to this crucial subset of our laws. 
Valparaiso University Law Review, Vol. 41, No. 2 [2007], Art. 5

702

That said, the claim that popular constitutionalism is a plausible alternative cannot rest on a bare assertion that people take the Constitution seriously (or seriously enough), even if they do. One still needs to explain how constitutional disagreements are going to be resolved. We know how judicial review works: parties have a dispute, one of them goes to court, we have a trial, the case is decided and appealed, and eventually the Supreme Court delivers an opinion. But what is the analogous process in a system of popular constitutionalism? What does it mean to say that constitutional controversies will be decided by the community at large? How does "the community" do that? How is this even coherent?

That I failed adequately to explain how popular constitutionalism works has probably been the most common criticism made of The People Themselves. It surprised me at first, because I thought this was pretty clear in the book. But when the point kept appearing, and not always from reviewers hostile to the book's sensibility and approach, I realized that the theoretical dimensions of popular constitutionalism-how it fits our political system and is meant to work-are embedded in the historical narrative and so spread across the entire book. The theory was evident to me because I had the whole picture in mind as I wrote. But it was not similarly apparent to readers approaching my story for the first time, and, in retrospect, it was a bit much to expect anyone to see the connection between a paragraph in the first chapter, a passage in the fourth, an argument in the epilogue, and so forth.

This Lecture is an effort to present the theory of popular constitutionalism in a more straightforward manner. Doing so will not resolve anyone's empirical doubts or settle the comparative institutional questions on which the acceptance or rejection of popular constitutionalism must ultimately rest. But it should provide a better framework in which to think about such matters.

That last paragraph is actually misleading insofar as it refers to "the" theory of popular constitutionalism. For there is no one theory. Popular constitutionalism, as such, is just a general concept or broad idea. As noted above, basically it's the idea that final authority to control the interpretation and implementation of constitutional law resides at all times in the community in an active sense. A "theory" of popular constitutionalism involves showing how this idea works or could be made to work. But there are countless institutional arrangements by which popular control can become meaningful. 
The central narrative in The People Themselves is, in fact, a story about how the practice of popular constitutionalism evolved over time so as to preserve the idea and its realization despite constantly changing political, legal, social, and cultural circumstances. Hence, the rowdy mobs of colonial America gave way to "departmentalism" in the 1790s, which was then supplemented by the creation of modern political parties in the 1830s. My objective in charting these developments was to show how popular constitutionalism, as a construct, could and did change, so that it need not depend on the political conditions in which it first emerged, but could be refined and updated to remain a viable part of American constitutionalism and democracy. ${ }^{7}$

Nevertheless, among the many possible accounts of popular constitutionalism that have been offered or could be imagined, there is one I find attractive and will elaborate here. It is the version developed by James Madison and articulated in essays he wrote as Publius and after. The most profound political thinker of his generation, Madison conceptualized a system of deliberative democracy, meant to apply equally to ordinary politics and constitutional control, whose general contours, once properly understood, seem to me as potentially relevant today as they were in his own time.

\footnotetext{
7 Given this narrative, reading The People Themselves (as some critics did, see Saikrishna Prakash \& John Yoo, Against Interpretative Supremacy, 103 MICH. L. REV. 1539, 1564 (2005) (book review)) to equate popular constitutionalism with eighteenth-century mobbing seems particularly thoughtless. The whole thrust of the book was to show how, even as American politics and society changed, and even as "the people" expanded to include poor white men and blacks and women, the basic commitment to popular control of the Constitution could be and was self-consciously preserved.

I recounted this history in detail through approximately 1840. I then passed quickly over the subsequent 165 years in a single chapter of thirty pages. This led to another frequent criticism: that one cannot assume popular constitutionalism might be relevant today without a similarly detailed treatment of the intervening years, which may have brought about its demise and disappearance. I ended the detailed history where I did because my expertise was exhausted and because a similar treatment of the rest of American history would have taken another 800 pages. Rather than do that, I simply touched on a few highlights to suggest how, contrary to conventional wisdom, the idea of popular constitutionalism did not fade from view, but remained vibrant and arguably dominant in American political culture until at least the middle of the twentieth century. My hope was that other legal historians might find the story interesting enough to carry it forward into later periods. And a number of scholars have begun to do just that. See, e.g., A Symposium on The People Themselves: Popular Constitutionalism and Judicial Review, 81 CHI.-KENT L. REV. 809-1182 (2006). Even more gratifying, most have said it would be a mistake to treat the Founding as a golden age of popular constitutionalism. The real peak, they say, came later, in their period, be it abolition or Reconstruction or the Progressive or New Deal eras. Sorting all this out will take time. Clearly, popular constitutionalism remained alive; just as clearly, it continued to evolve. There are important and interesting stories still to be told.
} 
Valparaiso University Law Review, Vol. 41, No. 2 [2007], Art. 5

704 VALPARAISO UNIVERSITY LAW REVIEW

Note the qualification "once properly understood." There is, at present, a particular understanding of Madison that dominates American constitutional thought. ${ }^{8}$ According to this view, Madison was frightened of popular politics and deeply suspicious of majority rule, which he had come to believe threatened to ruin the new nation. Having witnessed politics in the states during the critical years just after the Revolution, more, having experienced state government first hand during an exasperating three-year stint in the Virginia Assembly, Madison had come to see democracy as the problem, particularly as it was practiced in the popularly-elected state legislatures. Yet rather than give in to despair, as some of his contemporaries were wont to do, Madison set out to find an answer. And he succeeded brilliantly, shepherding in a new national Constitution while creating what Gordon Wood has called a fresh "American [s]cience of [p]olitics." 9

The critical problem, as Madison saw it, was finding a way to choose representatives capable of governing without succumbing to the corrupting influences of faction, insularity, and lust for popularity or power. Thus, in his most celebrated essay, Federalist 10, Madison famously explained how size could do the trick. A large republic meant large election districts. The sheer number of voters and variety of interests subsumed in such districts would make getting elected impossible for candidates who had parochial views or who were beholden to narrow interests. As broad support became a practical necessity for office, elections would be "more likely to centre on men who possess the most attractive merit, and the most diffusive and established characters." 10 Only the wisest, best educated, and most publicly spirited would be picked to serve: "a chosen body of citizens, whose wisdom may best discern the true interest of their country, and whose patriotism and love of justice, will be least likely to sacrifice it to temporary or partial considerations."11

\footnotetext{
8 One finds this reading, for example, in the introductory materials in leading constitutional law casebooks. See GEOFFREY R. STONE ET AL., CONSTITUTIONAL LAW 12-26 (5th ed. 2005). The same understanding is reflected in innumerable articles, see Larry D. Kramer, Madison's Audience, 112 HARV. L. REV. 611, 612-14 \& nn.2-21 (2001) (citing authorities), and in the writings of our leading constitutional historians. See JACK N. RAKOVE, ORIGINAL MEANINGS, POLITICS AND IDEAS IN THE MAKING OF THE CONSTITUTION 35-56 (1996) [hereinafter RAKOVE, ORIGINAL MEANINGS]; Gordon S. Wood, Interests and Disinterestedness in the Making of the Constitution, in BEYOND CONFEDERATION: ORIGINS OF THE CONSTITUTION AND AMERICAN NATIONAL IDENTITY 69-93 (Richard Beeman, Stephen Botein \& Edward C. Carter eds., 1987) [hereinafter Wood, Interests and Disinterestedness]. It pervades the political science literature.

9 GORDON S. WOOD, THE CREATION OF THE AMERICAN REPUBLIC, 1776-1787, at 593 (1969)

[hereinafter WOOD, CREATION] (emphasis omitted).

10 The Federalist No. 10, at 63 (James Madison) (Jacob E. Cooke ed., 1961)

$11 \quad$ Id. at 62.
} 
Better still, enlarging the republic (and so taking in a greater variety of interests) made it "less probable that a majority of the whole will have a common motive to invade the rights of other citizens; or if such a common motive exists, it will be more difficult for all who feel it to discover their own strength, and to act in unison with each other." 12 In other words, size would also dilute faction, to such an extent that our wiser, justice-loving representatives could use their superior wisdom relatively unencumbered by the intense pressures that self-interested groups could bring to bear in distorting government in a smaller society. The result: a deliberative democracy in which elections are structured to sift out an elite that can then deliberate on our behalf free from the irrationality, unreasonableness, and self-interest that make popular politics such a hazard. ${ }^{13}$

Interestingly, Madison nowhere refers to the judiciary in this argument. Indeed, none of Madison's work during the critical years leading up to Ratification paid much attention to courts. His letters and private writings make clear that he thought the judicial department too weak to play a meaningful role in constitutional enforcement, unless it was to lend a bit of additional weight to the executive in a Council of Revision. ${ }^{14}$ But other than a short passage in Federalist 39 (suggesting that the Supreme Court might act as an impartial umpire in disputes between the national government and the states), ${ }^{15}$ Madison as Publius had essentially nothing to say about the third branch.

Still, the underlying premise of Madison's theory, thus understood, is eminently compatible with an idea like judicial supremacy. In politics, we

$12 \quad$ Id. at 64.

13 This by now conventional reading of Madison is most clearly stated and synthesized in Cass R. Sunstein, Interest Groups in American Public Law, 38 STAN. L. REV. 29 (1985).

14 See Letter from James Madison to Thomas Jefferson (Oct. 24, 1787), in 10 JAMES MADISON, THE PAPERS OF JAMES MADisOn 206, 211 (Robert A. Rutland et al. eds., 1977) [hereinafter PAPERS OF MADISON] ("a State which would violate the Legislative rights of the Union, would not be very ready to obey a Judicial decree in support of them"); James Madison, Madison's Observations on Jefferson's Draft of a Constitution for Virginia (1788), in 6 THE PAPERS OF THOMAS JEFFERSON 308, 315 (Julian P. Boyd ed., 1952) [hereinafter Madison, Observations on Jefferson's Draft] (worrying about judicial review because "as the Courts are generally the last in making their decisions, it results to them by refusing or not refusing to execute a law, to stamp it with its final character. This makes the Judiciary Department paramount in fact to the Legislature, which was never intended and can never be proper."); Notes of James Madison (June 6, 1787), reprinted in 1 THE RECORDS OF THE FEDERAL CONVENTION OF 1787, at 138 (Max Farrand ed., rev. ed. 1966) [hereinafter FARRAND] (comments of James Madison) (arguing for Council of Revision rather than executive veto on grounds that the executive's "firmness ... wd. need support"); Letter from James Madison to Caleb Wallace (Aug. 23, 1785), in JAMES MADISON: WRITINGS 39, 41-43 (Jack N. Rakove ed., 1999) [hereinafter MADISON: WRITINGS] (approving a Council of Revision and discussing the judiciary with no mention of judicial review).

15 The FEDERALIST NO. 39, at 256 (James Madison) (Clinton Rossiter ed., 1961). 
Valparaiso University Law Review, Vol. 41, N 0.2 [2007], Art. 5

do our best to shift authority to an elite removed as far as possible from direct popular control or influence. Is it not natural when it comes to the Constitution, the fundamental law of the land, to do something similar and even more dramatic? Judicial supremacy seems wholly agreeable with this view of deliberative democracy, which is why so many defenders and proponents of the Supreme Court's authority have called on Madison for support. ${ }^{16}$

But reading Madison this way misstates his thinking and misrepresents his theory, which were more democratic than the received wisdom understands. Not that faction and majority tyranny were not central preoccupations in Madison's mind. They were, and his anxiety about the risks of popular government was real. Madison unquestionably saw certain forms of democratic politics as noxious and unjust, and he believed it possible to engineer the government's internal structure to minimize these. But structural innovations were mere "auxiliary precautions" to a more basic and primary "dependence on the people."17 Madison's hope, his whole purpose, was to make democratic politics work, not to minimize the extent to which it interfered with a ruling elite. "In bestowing the eulogies due to the partitions and internal checks of power," he wrote, expressing sentiments acted upon throughout his lifetime, "it ought not the less to be remembered, that they are neither the sole nor the chief palladium [that is, safeguard] of constitutional liberty. The people who are the authors of this blessing, must also be its guardians." 18 Madison was, above all, a committed republican who believed in popular government and believed that the people must control the government and laws at all times: someone for whom an idea like judicial supremacy was and could only be anathema, a selling out of the very raison d'etre of the American Revolution that was his life's passion. ${ }^{19}$

16 See Richard A. Epstein, Toward a Revitalization of the Contract Clause, 51 U. CHI. L. REV.703, 705, 711-12 (1984); Thomas W. Merrill, The Economics of Public Use, 72 CORNELL L. REV. 61, 115 (1986); Frank I. Michelman, Foreword: Traces of Self Government, 100 HARV. L. REV. 4 (1986); Norman R. Williams II, Rising Above Factionalism: A Madisonian Theory of Judicial Review, 69 N.Y.U. L. REV. 963, 985 (1994).

17 Though "experience has taught mankind the necessity of auxiliary precautions," Madison wrote in Federalist 51, "[a] dependence on the people is no doubt the primary controul on the government." THE FEDERALIST No. 51, at 349 (James Madison) (Clinton Rossiter ed., 1961). 18 James Madison, Government of the United States, NAT'L GAZETTE, Feb. 4, 1791, in 14 PAPERS OF MADISON, supra note 14, at 217-18 [hereinafter Madison, Government].

19 To some extent, the prevailing misinterpretation of Madison comes from focusing so obsessively on what he wrote between the calling of the Philadelphia Convention and the successful conclusion of Ratification. Indeed, I toyed with titling this lecture "James Madison 
Kramer: "The Interest of the M an": James M adison, Popular Constitutional

2006] James Madison, Popular Constitutionalism

$$
* * *
$$

This is not the place to establish the coherence and consistency of Madison's actions and political philosophy over time. I do, however, need to make two historical points as necessary background to understanding the theory of deliberative democracy and popular constitutionalism he articulated in The Federalist and fleshed out in essays published a few years later.

First, we must put aside certain assumptions we tend to make, consciously and unconsciously, when thinking about the Founding. Close your eyes and picture Madison. Quick. Don't think. Just picture the person. Who do you see? An old man, I bet. Sober, solemn, a bit stern looking: a "Founding Father." But forget the "father" part, because these grave old men did not found the United States. Our Founders, with a few notable exceptions, were young men. Most were in their twenties and thirties when the American Revolution began, still trying on identities and deciding who they were or would be. And the Revolution gave them an

\footnotetext{
was Born Before 1786, and He Died After 1790," because a very different Madison emerges if we read what he said when the Constitution was composed against the background of his whole political life. Madison's entire career was dedicated to making republican government work. He read and thought and wrote about it constantly. Yet most constitutional and political theorists seem to know only the twenty-nine essays he penned as Publius (and not even all of these), essays that were produced at a particular moment (albeit a very important moment) to address a particular set of problems and exigencies (albeit important problems and exigencies). Even writers who pay attention to Madison's earlier and later writings seem caught in Publius's thrall. So dazzled are they by the conventional reading of The Federalist that anything Madison wrote or said elsewhere that looks inconsistent is dismissed as driven by politics (as if getting the Constitution adopted wasn't political), or ignored on the ground that Madison was (with apologies to Senator Kerry) a "flip-flopper" who changed positions when it became expedient to do so. For an insightful, if ultimately unsuccessful, recent essay on the question of Madison's consistency, see GORDONS. WOOD, Is There a "James Madison Problem"?, in REVOlUtionARY CHARACTERS: WHAT MADE THE FOUNDERS DIFFERENT 143, 154-65 (2006).

I believe this treatment very much misunderstands Madison, who was, as these things go, quite consistent over the fifty plus years of his public life. Not that Madison's thinking never changed. Obviously his ideas evolved as he confronted new issues and circumstances and learned that things did not always work as expected. Madison was indeed a "nationalist" in the 1780s, a "state's rights" supporter in the 1790s, and a nationalist again in the 1830s. But not because he had abandoned principles or changed beliefs. Circumstances were different, the problems were different, and unanticipated developments (such as the executive's ability to control the national political agenda) upended earlier assumptions. Like all really good theorists, Madison adapted his ideas to what life and experience taught him. But his fundamental commitments did not change, and his core ideas and beliefs remained consistent over the years. If writers have missed this, it is partly because they have been asking the wrong questions - looking at too particular a level of detail or focusing on outcomes rather than reasoning. But the failure to comprehend Madison's actions over time also results from misunderstanding his theory more generally, a problem I hope to address here.
} 
Valparaiso University Law Review, Vol. 41, N0. 2 [2007], Art. 5

answer. It shaped their lives and turned them into radicals and revolutionaries in the fullest sense of the words. ${ }^{20}$

This was particularly true of Madison. ${ }^{21}$ Like many young men of talent, he longed for something to give his life purpose, and he found that something in the Revolution. Born in 1751, the eldest son of a wealthy planter, Madison would in normal circumstances have been expected to inherit and run the family estate. But the life of a well-to-do gentleman farmer held little appeal for young James, and he made a break early by choosing to attend the College of New Jersey (as Princeton was then called) rather than follow Virginia's other privileged sons to William and Mary. Suddenly Madison found himself surrounded by brilliant young men from throughout the colonies, discussing philosophy and religion and all the important issues of the day. It was an exciting, cosmopolitan, intellectuallydiverse milieu unlike anything he had experienced back home in provincial Virginia. Madison studied hard and excelled as a student, completing his degree a year early. He also played hard: co-founding the American Whig Society, writing ribald poetry, and thoroughly enjoying the idle amusements that constituted college life in the mid-eighteenth century.

When he graduated in 1771, about the last thing James Madison wanted was to return to what now seemed an unbearably dull life in Orange County, Virginia. He wrote his father for permission to remain in Princeton through the winter and perhaps to return again after a brief visit home the following spring. Madison's reasons for staying are not entirely clear, though anyone whose life was changed by college can probably guess. In his only surviving letter, Madison tells his father "I was so particular in my last with regard to my determination about staying in Princeton this Winter

\footnotetext{
20 Stanley Elkins \& Eric McKitrick, The Founding Fathers: Young Men of the Revolution, 76 POL. SCI. Q. 181, 203 (1961):

At the outbreak of the Revolution George Washington, at 44, was the oldest of the lot [of those who later led the campaign to adopt the Constitution]; six were under 35 and four were in their twenties.... Nearly half of the Federalist group-Gouverneur Morris, Madison, Hamilton, and Knox-quite literally saw their careers launched in the Revolution. The remaining five-Washington, Jay, Duane, Wilson, and Robert Morris-though established in public affairs beforehand, became nationally known after 1776 and the wide public recognition which they subsequently achieved came first and foremost through their identification with the continental war effort.

21 The brief sketch that follows is drawn mainly from IRVING BRANT, JAMES MADISON: THE VIRGINIA REVOLUTIONIST 41-135 (1941), as updated and supplemented by RALPH KETCHUM, JAMES MADISON: A BIOGRAPHY 8-67 (1990), and JACK N. RAKOVE, JAMES MADISON AND THE CREATION OF THE AMERICAN Republic 1-21 (2d ed. 2002). See also Douglass Adair, James Madison's Autobiography, 2 WM. \& MARY Q. 191 (1945).
} 
coming that I need say nothing more in this place, my sentiments being still the same." 22 Madison's biographers have assumed that he stayed because he was ill, this based on a comment Madison scribbled some sixty years later in a short autobiographical summary. ${ }^{23}$ Yet Madison's contemporaneous letter sounds less like someone pleading illness than like a typical twenty-year-old college student who wants to stay with friends and spend as little time at home as possible. Madison was notoriously frail, of course, and he probably was ill. But he seems to have led an active social life during his extra time at Princeton, and it is likely that any infirmity was not particularly dire, though it did make a good excuse to give his family for remaining in New Jersey. ${ }^{24}$

But not for long. Filial duty, not to mention lack of resources, forced a reluctant Madison to return home in April, 1772. The two years that followed were among the lowest of his life. Whatever disease or disability afflicted Madison was at its worst during this period. Historians and biographers have long puzzled over Madison's illness, though I am inclined (with Irving Brant) to see it as a "psychic trauma," most likely some form of depression. ${ }^{25}$ The physical symptoms were real, but triggered and exacerbated by his emotional state. And Madison suffered greatly from the time he returned to Montpelier until he found his vocation in revolutionary politics several years later.

Whatever the source or nature of Madison's illness, he clearly was depressed being back home. And not solely because he was sick. He was also bored, and lost. With his father still actively managing the plantation, Madison's chief responsibility became tutoring his younger siblings, a dispiriting comedown from the joys of studying and conversing with teachers and friends at college. Worse than bored, Madison felt boring: exiled to a place where nothing interesting happened or would happen. "I am sorry my situation affords me nothing New Curious or entertaining to

22 Letter from James Madison to James Madison, Sr. (Oct. 9, 1771), in 1 PAPERS OF MADISON, supra note 14 , at $68-69$.

${ }_{23}$ See Adair, supra note 21, at 197. "His health being at the time too infirm for a journey home, he passed the ensuing winter in Princeton ...." Id.

24 As Madison's leading biographer, Irving Brant, notes:

[I]t appears that Madison had been well enough in the past summer to wish for the use of a new coat. Two weeks before writing, he had moved among the commencement visitors and planned to go to see one of them elsewhere in New Jersey. Though unable to go home, he nonchalantly asked for money with which to buy a horse in the spring and shows plainly that he wants it to carry him not only from Princeton to Montpelier, but back again for another summer of study.

BRANT, supra note 21, at 99.

25 Id. at 106-07. 
pay you for your agreeable information \& remarks," he wrote his classmate and close friend William Bradford, who now lived in Philadelphia. "You being at the Fountain-Head of Political and Literary Intelligence and I in an Obscure Corner - You must expect to be greatly [the] loser on that score by our Correspondence." 26

As time passed and Madison's mood worsened, he drifted toward melodrama, as people his age often will. His life was over before it had begun; he would not do or experience anything exciting. He would not make a difference. Hopelessness set in. He came to see his physical afflictions as fate and concluded that he was not long for the world. He unburdened himself in letters to friends, revealing his ambitions and despair, his grandiosity and his gloomy sense that death was nigh. These letters would be embarrassing had not most of us also sometimes felt this way at Madison's age. Writing again to Bradford:

[A] watchful eye must be kept on ourselves lest while we are building ideal monuments of Renown and Bliss here we neglect to have our names enrolled in the Annals of Heaven. These thoughts come into my mind because I am writing to you and thinking of you. As to myself I am too dull and infirm now to look for any extraordinary things in this world for I think my sensations for many months past have intimated to me not to expect a long or healthy life, yet it may be better with me after some time tho I hardly dare expect it and therefore have little spirit and alacrity to set about any thing that is difficult in acquiring and useless in possessing after one has exchanged Time for Eternity. But you have Health Youth Fire and Genius to bear you along through the high tract of public Life and so may be more interested and delighted in improving on hints that respect the temporal though momentous concerns of man. ${ }^{27}$

Yet things were happening in and around Madison's small world that would soon shake up his life and give him a direction and purpose. Madison was, of course, aware of the epochal events taking shape in the North American colonies, but he showed little interest prior to 1774. Near the end of a letter he wrote to Bradford in September, 1773, for example,

26 Letter from James Madison to William Bradford (Apr. 28, 1773), in 1 PAPERS OF MADISON, supra note 14 , at $83-84$.

27 Letter from James Madison to William Bradford (Nov. 9, 1772), in 1 PAPERS OF MADISON, supra note 14 , at $74-75$. 
Madison commented briefly on the "scarcity of circulating cash" in Virginia, but sheepishly excused this departure from his usual fare by noting, "I do not meddle with Politicks but this Calamity lies so near the heart of every friend of the Country that I could not but mention it." 28 As late as January, 1774 , his reaction to news of the Boston Tea Party was chiefly to hope that "Boston may conduct matters with as much discretion as they do with boldness." After offering the additional thought that "Political Contests are necessary sometimes ... to afford exercise and practise and to instruct in the Art of defending Liberty and property," Madison returned to more comfortable topics. "But away with Politicks! Let me address you as a Student and Philosopher \& not as a Patriot now." 29

That all changed after England answered Boston's defiance by closing the port of Boston, abrogating the Massachusetts Charter, and requiring Bostonians to quarter and feed British troops. America exploded when news of the Coercive Acts reached its shores in the summer of 1774. There was open rebellion in Massachusetts, as citizen-soldiers began massing outside Boston, and the other colonies soon rallied to her side. Madison, too, caught Patriot fever and became a convert to the cause. He swiftly transformed into a militant Whig, advocating preparations for war, boasting of his neighbors' willingness to fight, and hoping "it will be a general thing thro'ought this province." 30

The American Revolution became James Madison's life. Ralph Ketchum explains:

From the uncertain, introspective, affectedly grave youth he had been in the year after he graduated from college, he had become a man consumed by a cause. He had henceforth his vocation: he was a nation builder. During the galvanizing years before 1776, when the great revolution in loyalty took place (what John Adams called the real American Revolution), James Madison shared, emotionally and intellectually, a traumatic excitement vital to the founders of the new United States. By the time of the battles of Lexington and Concord, Madison had found the purpose and adopted the ideals that were to motivate

\footnotetext{
28 Letter from James Madison to William Bradford (Sept. 25, 1773), in 1 PAPERS OF MADISON, supra note 14, at 95, 97 (footnote omitted).

29 Letter from James Madison to William Bradford (Jan. 24, 1774), in 1 PAPERS OF MADISON, supra note 14, at 104-05.

30 Letter from James Madison to William Bradford (Nov. 26, 1774), in 1 PAPERS OF MADISON, supra note 14 , at 129 (footnote omitted).
} 
Valparaiso University Law Review, Vol. 41, N0. 2 [2007], Art. 5

and guide him during forty years in public life and twenty years as his country's authentic sage. ${ }^{31}$

And what was that purpose? What were those ideals? We tend today to lose sight of what Gordon Wood has aptly called the "radicalism of the American Revolution."32 The same cannot be said, however, for the Americans who made it happen. In their eyes, the Revolution had "reduc[ed] to practice, what, before, had been supposed to exist only in the visionary speculations of theoretical writers." 33 So marveled St. George Tucker in 1803, boasting how "The world, for the first time since the annals of its inhabitants began, saw an original written compact formed by the free and deliberate voices of the individuals disposed to unite in the same social bonds; thus exhibiting a political phenomenon unknown to former ages ...."34 This idea - that a nation could be created and governed based explicitly on the consent of its people-was political heresy in the 1770s and 1780s, something contrary to all wisdom and experience. Yet it was precisely this idea on which the American Revolution was staked, and those who embraced it were, in the context of their times, radicals and idealists.

Like radicals and idealists in other ages and at other times, moreover, the cause they fought for infused meaning into their lives, and they were determined to see it through. The American Revolution was dedicated first and foremost to the principle that "the people" governed, that "the people" supplied government with its energy and direction, and that monarchical institutions - that is, institutions not controlled by or accountable to the people-needed to be eradicated. Making popular government work was both the reason for and triumph of our Revolution, and it was this ideal that Madison committed his life to achieving.

Knowing only what I have just recounted should be enough to give us pause when we consider the conventional story about Madison. Such doubts grow stronger, moreover, if we think about Madison's passion for the cause and its role in his life alongside his later actions: his alliance with Jefferson, his opposition to Hamilton, his role in forming the Republican Party, and his conduct as Secretary of State and President. All these are hard to reconcile with the conservative anti-democrat who fills the pages of today's books and journals. Of course, it could be that Madison was one

KETCHUM, supra note 21, at 67.

GORDON S. WOOD, THE RADICALISM OF THE AMERICAN REVOLUTION (1991).

St. George Tucker, On Sovereignty and Legislature, in BLACKSTONE'S COMMENTARIES app.A, reprinted in ST. GEORGE TUCKER, VIEW OF THE CONSTITUTION OF THE UNITED STATES WITH SELECTED WRITINGS 19 (Liberty Fund 1999) (1803).

$34 \quad$ Id. 
person before 1786 and after 1790 and a different person for the four years in between. Or maybe we've been misreading what he had to say in those critical years.

I will return to this theme below. There is, however, a second background fact to bear in mind while reading Madison, this one concerning the battles that dominated politics in the years after the Revolution, when Madison's thinking matured and came into focus. The 1780s and 1790s witnessed a steady stream of constitutional crises, one controversy following another, until the young republic teetered on the brink of disunion. There was the problem of financing the war, the fight over negotiating with Spain to open the Mississippi, the failure of the Articles of Confederation, Shay's Rebellion, Ratification, Hamilton's plans for assumption and financing the debt, the national bank, the French Revolution and American neutrality, the Whiskey Rebellion, the Jay Treaty, the quasi-war with France, Fries Rebellion, the Alien and Sedition Acts, the Virginia and Kentucky Resolves, the deadlocked election of 1800, and much more. The 1790s, in particular, were a period of unparalleled economic prosperity, yet domestic political strife was ferocious and displayed a deep rancor and paranoia.

Naturally, each incident had its own peculiar causes and explanations. But if we understand the period properly, we find one fundamental disagreement underlying, and in many instances motivating, these controversies, and that is the nature of popular participation in controlling government. ${ }^{35}$ On one view - the conservative view associated with Federalism in the 1790 s - republicanism meant no more than the power of the people to choose their leaders at election time. Between elections, ordinary citizens had no direct agency or authority. They reverted to subjects, whose duty and obligation was to obey what their political leaders decided. "It is often said that 'the sovereign and all other power is seated in the people,"' Benjamin Rush complained during his brief period of High Federalism. "This idea is unhappily expressed. It should be-'all power is derived from the people.' They possess it only on the days of their elections. After this, it is the property of their rulers, nor can they exercise it or resume it, unless it is abused." 36

35 Cf. Colleen A. Sheehan, Madison v. Hamilton: The Battle over Republicanism and the Role of Public Opinion, 98 AM. POL. SCI. REV. 405 (2004).

36 Benjamin Rush, On the Defects of the Confederation (1787), in THE SELECTED WRITINGS OF BENJAMIN Rush 26, 28 (Dagobert D. Runes ed., 1947); see James P. Martin, When Repression Is 
Valparaiso University Law Review, Vol. 41, No. 2 [2007], Art. 5

714

Though not everyone spoke of office-holding as a property right, sentiments like these were pervasive among Federalists. An editorial in the Columbia Centinal thus explained how "the sovereignty of the people is delegated to those whom they have freely appointed to administer [the] constitution, and by them alone can be rightly exercised, save at the stated period of election, when the sovereignty is again at the disposal of the whole people." 37 Between elections, however, the people needed only to listen and to obey.

This is why Federalists so resented the "Democratic-Republican societies" of the mid-1790s, which sought self-consciously "to act as intermediaries between [the] political elite and a larger local citizenry," and why they were so discomfited by the new forms of electioneering and politicking that emerged over the course of the decade. ${ }^{38}$ In the Federalist world-view, ordinary citizens had no business trying to influence the direction of government outside of elections, unless through respectful petitions "humbly" beseeching duly constituted authorities for relief. ${ }^{39}$ Individuals might offer a "decent manly statement of opinion," 40 yet free speech did not go so far as to include the right to publish something whose "professed design is the superintendence of [the] government" or whose "evident tendency, by obtaining an influence, is to lessen the power of officers of government, and to lead, or rather to drive, the legislature, where ever they please." 41 Oliver Wolcott went so far as to say it was "unlawful" for any group or organization to assemble "for the avowed purpose of a general influence and control upon the measures of government." 42

Democratic and Constitutional: The Federalist Theory of Representation and the Sedition Act of 1798, 66 U. CHI. L. REV. 117, 166-69 (1999).

37 Order, Columbian Centinel, Sept. 3, 1794, at 1.

38 David Waldstreicher, Federalism, the Styles of Politics, and the Politics of Style, in FEDERALISTS RECONSIDERED 99, 101-11, 132 (Doron Ben-Atar \& Barbara B. Oberg eds., 1998). The Democratic-Republican societies flourished briefly from 1793-96, until they were publicly condemned by George Washington and lost credibility. See STANLEY ELKINS \& ERIC McKitrick, THe Age of Federalism 487 (1993); Eugene Perry LinK, THe DemocraticREPUBLICAN SOCIETIES 175-209 (1942); JAMES ROGER SHARP, AMERICAN POLITICS IN THE EARLY REPUBLIC: THE NEW NATION IN CRISIS 100-04 (1993).

39 Martin, supra note 36, at 160-66; see Seth Cotlar, The Federalists' Transatlantic Cultural Offensive of 1798 and the Moderation of American Democratic Discourse, in BEYOND THE FOUNDERS: NeW APPROACHES TO THE POLITICAL History OF THE EARLY AMERICAN REPUBliC (Jeffrey L. Pasley, Andrew W. Robertson \& David Waldstreicher eds., 2004).

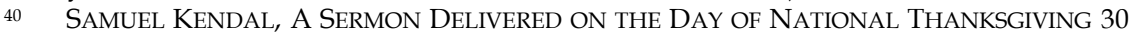
(Samuel Hall 1795).

41 To the Vigil, GAZETTE OF THE U.S., Dec. 6, 1794, at 2.

421 MEMOIRS OF THE ADMINISTRATIONS OF WASHINGTON AND JOHN ADAMS 178-79 (George Gibbs ed., 1846) (Oliver Wolcott ed., Mar. 26, 1795). 
Particularly after 1793, as news spread of the Terror in France, Federalists grew obsessed with the need to make citizens show "respect" and "deference" and "obedience" to constituted authorities. Nathaniel Emmons preached a sermon in 1799 whose talk about what "subjects" owed their "rulers" makes Republican suspicions that their opponents were secretly plotting monarchy appear almost reasonable:

The duty of submission naturally results from the relations, which subjects bear to their rulers. There would be no propriety in calling the body of the people subjects, unless they were under obligation to obey those in the administration of government. Every people either directly or indirectly promise submission to their rulers. Those, who choose their civil magistrates, do voluntarily pledge their obedience, whether they take the oath of allegiance or not. By putting power into the hands of their rulers, they put it out of their own; by choosing and authorizing them to govern, they practically declare, that they are willing to be governed; and by declaring their willingness to be governed, they equally declare their intention and readiness to obey. ${ }^{43}$

The Republican view, which is to say the view espoused by Madison, Jefferson, and their followers, was very nearly the opposite. The bedrock principle of republicanism, they said, its essence and most basic requirement, was that "the censorial power is in the people over the government, and not in the government over the people." 44 Republicans were scandalized by statements like those quoted above, which led Jefferson mockingly to label his opponents "monocrats." 45 The idea that a citizen became a subject between elections outraged and alarmed Jefferson and his supporters. The American Revolution had not been fought merely to establish a sequence of mini-monarchies time-limited by elections. The suffrage was a device to secure popular control, but elected officials were responsible to "the sense of the people" at all times. ${ }^{46}$ It was, indeed, this

43 Nathaniel Emmons, A Discourse Delivered on the National Fast (1799), in 2 AMERICAN Political Writing During THE FOUNDING ERA 1023, 1027 (Charles S. Hyneman \& Donald S. Lutz eds., 1983).

44 James Madison, Speech in Congress on "Self-Created Societies" (Nov. 27, 1794), in MADISON: WRITINGS, supra note 14, at 552.

45 DUMAS MALONE, JEFFERSON AND THE ORDEAL OF LIBERTY 265 (1962).

46 The quote comes from a letter Madison wrote to Jefferson during the crisis with France in which Madison approved Jefferson's suggestion that Congress do its best to slow down what both saw as Adams's effort to rush the nation into war by "an adjournment for the purpose of 
precise understanding that motivated and justified the institutional experiments Republicans essayed throughout the 1790s: the DemocraticRepublican Societies, party newspapers, organized petition campaigns, the Virginia and Kentucky Resolves, the formation of a political party with party discipline, and so on, all efforts to keep the government in line with popular opinion, and all opposed and condemned by Federalists (who nevertheless frequently found themselves unwittingly forced to adopt the same tactics).

The need to respect and preserve the paramount authority of the community, particularly on constitutional questions, was a constant theme in Madison's writings, both as Publius and after. I have already adverted to Madison's largely overlooked admonition in Federalist 51 that "A dependence on the people is no doubt the primary controul on the government," with structural devices serving only as "auxiliary precautions." 47 Federalist 51 deals with separation of powers. But Madison had made the same point, and at greater length, a week earlier in an essay on federalism:

The adversaries of the Constitution seem to have lost sight of the people altogether in their reasonings on this subject; and to have viewed these different establishments [the state and federal governments], not only as mutual rivals and enemies, but as uncontrouled by any common superior in their efforts to usurp the authorities of each other. These gentlemen must here be reminded of their error. They must be told that the ultimate authority, wherever the derivative may be found, resides in the people alone; and that it will not depend merely on the comparative ambition or address of the different governments, whether either, or which of them, will be able to enlarge its sphere of jurisdiction at the expense of the other. Truth no less than decency requires, that the event in every case, should be supposed to depend on the sentiments and sanction of their common constituents. ${ }^{48}$

consulting the Constituents on the subject of war." Letter from James Madison to Thomas Jefferson (Apr. 2, 1798), in 17 PAPERS OF MADISON, supra note 14, at 104-05.

47 THE FEDERALIST No. 51, supra note 17 , at 349.

48 The Federalist No. 46, at 315-16 (James Madison) (Clinton Rossiter ed., 1961). Federalist 46 was published on January 29, 1788; Federalist 51 came out a week later, on February 6. 
Madison did not emphasize in these essays that popular control was constant or that it would not be surrendered between elections, because in 1788 the issue had not yet been formulated in these terms. It emerged as such only a few years later, when Federalists began denouncing opposition to their measures on the ground that any "appeal to the people" constituted "a gross violation offered to Freedom of Deliberation, in the constituted authorities." 49 As battle lines formed around this fundamental question of republican government, Madison again took up his pen to make his thinking clear.

Between November, 1791 and December, 1792, Madison published at least eighteen unsigned essays in the National Gazette, a newspaper he had helped launch that was edited by his friend and former Princeton classmate, Philip Freneau. ${ }^{50}$ Madison's notes for these essays indicate that he considered them an extension of the research and thinking he had done in preparing for the Constitutional Convention and in writing The Federalist. ${ }^{51}$ The essays filled out Madison's ideas about republican government and the threats it faced, informed by further reading and, more important, by several years of experience under the new Constitution. Among his core messages, a point to which he returned again and again, was the primacy of popular opinion in controlling a republican government, and the concomitant obligation this imposed on citizens to remain vigilant and involved. ${ }^{52}$

"Public opinion sets bounds to every government, and is the real sovereign in every free one," began an early essay titled Public Opinion, in which Madison laid out his understanding of the respective roles of citizens and government officials. ${ }^{53}$ Extending an idea borrowed from David

49 The quote is from John Fenno, editor of the Federalist newspaper and administration Mouthpiece, The Gazette of the United States. Fenno was complaining about a petition campaign that had been organized by opponents of the Jay Treaty in an effort to persuade Congress not to enact enabling legislation. GAZETTE OF THE U.S., May 5, 1796, at 3.

50 Colleen Sheehan has argued that Madison published an overlooked nineteenth essay. Colleen A. Sheehan, Madison's Party Press Essays, 17 INTERPRETATION 355, 356-57 (1990) [hereinafter Sheehan, Party Press].

51 LANCE BANNING, THE SACRED FIRE OF LIBERTY: JAMES MADISON AND THE FOUNDING OF THE FeDERAL RePUblic 349, 351 (1995); Editorial Note, Madison's National Gazette Essays, 19 Nov. 1791-20 \& Dec. 1792, in 14 PAPERS OF MADISON, supra note 14, at 110-12; Colleen A. Sheehan, Madison and the French Enlightenment: The Authority of Public Opinion, 59 WM. \& MARY Q. 925, 927 (2002) [hereinafter Sheehan, Public Opinion].

52 See Sheehan, Party Press, supra note 50, at 357, 371-73. Madison stressed this point because, as Lance Banning has noted, his political objective was "to arouse a public that appeared disturbingly complacent in the face of tendencies and programs that he now believed might be deliberately counterrevolutionary in intent." BANNING, supra note 51, at 350.

53 James Madison, Public Opinion, NAT'L GAZETTE, Dec. 19, 1791, in 14 PAPERS OF MADISON, supra note 14, at 170 [hereinafter Madison, Public Opinion]. 
Valparaiso University Law Review, Vol. 41, No. 2 [2007], Art. 5

Hume, ${ }^{54}$ Madison was clear that public opinion not only would, but should control the course of government. This was the first principle of republicanism, as Madison understood it. ${ }^{55}$ Yet Madison did not believe that elected officials should be mere ciphers. It might be one thing if public opinion had been considered and was settled, but "there are cases, where not being fixed, it may be influenced by the government." 56 And in such cases, public officials were responsible for educating their constituents and helping to shape their thinking. ${ }^{57}$ "This distinction [between settled and unsettled public opinion], if kept in view, would prevent or decide many debates on the respect due from the government to the sentiments of the people." 58

While Madison saw an important role for government officials in leading and helping to form public opinion, a point to which we shall return below, his position departed sharply from the Federalist view that anything "in the style of an appeal to the people" was not merely inappropriate but beneath the dignity of a respectable public officer, because political leaders were supposed " $t \mathrm{t}$ o save the people from their most dangerous enemy; to save them from themselves." 59 The widespread publicizing of such sentiments by Federalist leaders led Madison, in turn, to emphasize the public's critical responsibility to be constantly watchful of government, to ensure that it could never overstep its proper bounds. Madison was adamant and unrelenting on this score, issuing a succession of what were meant to be calls to action. From an essay on Charters: "Liberty and order will never be perfectly safe, until a trespass on the constitutional provisions for either, shall be felt with the same keenness that resents an invasion of the dearest rights; until every citizen shall be an ARGUS to espy,

54 "[A]s FORCE is always on the side of the governed," Hume wrote, "the governors have nothing to support them but opinion. It is therefore, on opinion only that government is founded; and this maxim extends to the most despotic and most military governments, as well as to the most free and most popular." DAVID HUME, Of the First Principles of Government, in ESSAYS: MORAL, POLITICAL AND LITERARY (Eugene F. Miller ed., rev. ed. 1985). For Hume the point is descriptive, whereas Madison converts it into a normative claim. See Colleen A. Sheehan, Public Opinion and the Formation of Civic Character in Madison's Republican Theory, 67 REV. POL. 37, 38-41 (2005) [hereinafter Sheehan, Civic Character].

55 See Sheehan, Party Press, supra note 50, at 357, 371; Colleen H. Sheehan, The Politics of Public Opinion: James Madison's "Notes on Government," 49 WM. \& MARY Q. 609, 618-19 (1992) [hereinafter Sheehan, Politics of Public Opinion].

56 Madison, Public Opinion, supra note 53, at 170.

57 Sheehan, Civic Character, supra note 54, at 44-48; Sheehan, Public Opinion, supra note 51, at 950-54; Sheehan, Party Press, supra note 50, at 373.

58 Madison, Public Opinion, supra note 53, at 170.

59 Gouverneur Morris, Speeches to Congress, 11 ANNALS OF CONG. 41, 76 (1802). 
and EGEON to avenge, the unhallowed deed." ${ }^{60}$ Returning to this theme in an essay titled Government of the United States, Madison lionized the people's role as guardians of constitutional liberty: "Their eyes must be ever ready to mark, their voice to pronounce, and their arm to repel or repair aggressions on the authority of their constitutions; the highest authority next to their own, because the immediate work of their own." 61 And yet again in an essay titled The Union. Who Are Its Real Friends?: "The real FRIENDS to the Union are those Who are friends to the authority of the people, the sole foundation on which the Union rests." 62

Madison's clearest explication of this position came in the final essay, a contrived debate between a fictional character named "Republican" and his nemesis, "Anti-republican," published in late December, 1792. I will quote this remarkable work at length, as it repays reading in the original. Madison apes the Federalist position, but not by much, and the language he put in Anti-republican's mouth was in fact routinely used by his opponents. Republican's responses, in the meantime, reflected Madison's own sentiments. "Who Are the Best Keepers of the People's Liberties?" Madison asked in the essay's title, and Republican's answer (from which I drew the title of my own book) was telling:

Republican., The people themselves. The sacred trust can be no where so safe as in the hands most interested in preserving it.

Anti-republican., The people are stupid, suspicious, licentious. They cannot safely trust themselves. When they have established government they should think of nothing but obedience, leaving the care of their liberties to their wiser rulers.

Republican., Although men are born free, and all nations might be so, yet too true it is, that slavery has been the general lot of the human race. Ignorant they have been cheated; asleep they have been surprized; divided the yoke has been forced upon them. But what is the lesson? That because the people may betray themselves, they ought to give themselves up, blindfold, to those who have an

\footnotetext{
60 James Madison, Charters, NAT'L GAZETTE, Jan. 18, 1792, in 14 PAPERS OF MADISON, supra note 14, at 191-92 [hereinafter Madison, Charters].

61 Madison, Government, supra note 18, at 218.

62 James Madison, The Union. Who Are Its Real Friends?, NAT'L GAZETTE, Mar. 31, 1792, in 14 PAPERS OF MADISON, supra note 14 , at 274.
} 
Valparaiso University Law Review, Vol. 41, N 0.2 [2007], Art. 5

interest in betraying them? Rather conclude that the people ought to be enlightened, to be awakened, to be united, that after establishing a government they should watch over it, as well as obey it.

Anti-republican.,... It is not the government that is disposed to fly off from the people; but the people that are ever ready to fly off from the government. Rather say then, enlighten the government, warn it to be vigilant, enrich it with influence, arm it with force, and to the people never pronounce but two words Submission and Confidence.

Republican., The centrifugal tendency then is in the people, not in the government, and the secret art lies in restraining the tendency, by augmenting the attractive principle of the government with all the weight that can be added to it. What a perversion of the natural order of things! to make power the primary and central object of the social system, and Liberty but its satellite. ${ }^{63}$

This is surprising stuff for scholars who have imbibed the conventional wisdom about Madison, and who might (if not tipped by his choice of pseudonyms) be inclined to assume that Madison identified more with Anti-republican than with Republican. ${ }^{64}$ Perhaps the same discrepancy explains why most of them ignore or slight the National Gazette essays. But passages like those quoted above surely do present a puzzle. After all, the conventional wisdom about Madison did not come from nowhere. Plainly Madison saw risks and dangers in democratic politics; plainly he wanted to temper popular majorities. His letters and papers, not to mention his essays as Publius, are filled with language displaying these efforts and anxieties. One sees hints even in Republican's responses to Anti-republican, which acknowledge rather than deny the latter's worries about the people. How, then, do we explain what look like two very different Madisons? Was he just confused and self-contradictory? Or did he, in fact, radically change his ideas, as most Madison scholars apparently believe?65 Did the cautious

63 James Madison, Who Are the Best Keepers of the People's Liberties?, NAT'L GAZETTE, Dec. 20, 1792, in 14 PAPERS OF MADISON, supra note 14, at 426-27.

64 Consider in this regard Anti-republican's next remark, in which he explained to Republican how "[w]onderful as it may seem, the more you increase the attractive force of power, the more you enlarge the sphere of liberty; the more you make government independent and hostile toward the people, the better security you provide for their rights and interests." Id. 65 See WOOD, REVOLUTIONARY CHARACTERS, supra note 19, at 151-55; Douglas W. Jaenicke, Madison v. Madison: The Party Press Essays v. The Federalist Papers, in REFLECTIONS ON THE 
Framer who wanted to put government into the hands of a disinterested elite subsequently shed his worries and become a simple democrat?

I think not, because both characterizations are inaccurate. Certainly Madison was concerned about the harm that could be done by popular majorities, as much so in the decades after Ratification as the decade before. The error in that part of the conventional wisdom is in its emphasis and accents: in seeing Madison in the 1780s as more repelled by democratic politics than he was, and, as a result, misreading him to embrace positions fundamentally at odds with his deep, emotional commitment to popular government and popular constitutionalism. Yet Madison always retained the sense (learned in the 1780s) that popular rule could be dangerous and unjust, and the Madison of the 1790s was never a simple democrat. Rather, in both decades, and throughout his life, for that matter, Madison's ideas about popular politics and his conception of republicanism were different and more complex (though also more consistent) than has generally been understood.

We can start the process of reconstructing Madison's thinking with his essays in Federalists 49-50. This may seem a curious place to begin, inasmuch as commentators typically read these essays as expressly rejecting what I have been calling popular constitutionalism. ${ }^{66}$ And, it seems, for good reason. In these papers, Madison went out of his way to criticize a suggestion made by his friend Thomas Jefferson in a 1783 draft of a constitution for Virginia. Jefferson had proposed to enforce the constitution by calling popular conventions whenever "[a]ny two of the three branches of government concur[ ] in opinion ... that a convention is necessary for altering this constitution, or correcting breaches of it ...."67 Such thinking was characteristic of Jefferson, a thoroughgoing popular constitutionalist who wanted direct, popular action to be the first and major line of defense in securing compliance with the constitution. Conventions would enable

CONSTITUTION: THE AMERICAN CONSTITUTION AFTER TWO HundRED YEARS 116 (R. Maidment \& J. Zvesper, eds.,1989); Sheehan, Public Opinion, supra note 51, at 927 n.7.

66 See RAKOVE, ORIGINAL MEANINGS, supra note 8, at 280-82 (the "ultimate conclusion" of these papers was that "No constitutional dispute within government could ever be safely remedied through an appeal to the people out-of-doors"); Jaenicke, supra note 65, at 136.

67 Draught of a Fundamental Constitution for the Commonwealth of Virginia (1783), in THOMAS JEFFERSON, NOTES ON THE STATE OF VIRGINIA 209, 221 (William Peden ed., 1954) (1787). 
Valparaiso University Law Review, Vol. 41, No. 2 [2007], Art. 5

this, but in a less chaotic and disorderly fashion than the mobbing and extralegal resistance relied on in the British constitutional tradition. ${ }^{68}$

Madison offered three pragmatic reasons against this sort of direct resort to the people, which most scholars read as confirming his desire to remove constitutional enforcement from popular control. First, Madison worried that a too-frequent appeal to the people would "deprive the government of that veneration, which time bestows on every thing, and without which perhaps the wisest and freest government would not possess the requisite stability." 69 Second, he said, "The danger of disturbing the public tranquility by interesting too strongly the public passions, is a still more serious objection against a frequent reference of constitutional questions, to the decision of the whole society."70 But "the greatest objection of all," according to Madison, was that the people would invariably side with the most popular branch of government, namely, the legislature. ${ }^{71}$ Nor was it an answer to this objection that the executive might sometimes be "a peculiar favorite of the people."72 For either way, the public decision "could never be expected to turn on the true merits of the question."73 Often, the very officials whose actions were at issue would gain election to the convention and, precisely because they were popular, would dominate it. Still more fatal, the irregular and evanescent nature of popular conventions made them highly susceptible to infection from "the spirit of pre-existing parties, or of parties springing out of the question itself." 74 As a result, "The passions ... not the reason, of the public, would sit in judgment" when "it is the reason of the public alone that ought to controul and regulate the government." 75

\footnotetext{
68 On constitutional enforcement under the British constitution, see KRAMER, THE PEOPLE THEMSELVES, supra note 1 , at 24-29. 
Plainly this reasoning stands in considerable tension with Madison's many statements in the National Gazette insisting that " $t]$ he people who are the authors of [the Constitution], must also be its guardians."76 It is similarly at odds with Madison's reliance in Federalists 45-46 on popular enforcement to secure federalism, and with his comment in Federalist 51 that the people are meant to provide "the primary controul on the government." 77 The contradiction is evident even in Federalist 49 itself, which begins by recognizing that because "the people are the only legitimate fountain of power" it is "the people themselves[,] who, as the grantors of the [Constitution], can alone declare its true meaning and enforce its observance," and which concludes by insisting that "it is the reason of the public alone that ought to control and regulate the government." 78

Statements like these (and countless others that could be cited) make clear that Madison embraced popular constitutionalism and, no less than Jefferson, believed that the public had a right and a responsibility to enforce the Constitution. But, then, why did he reject Jefferson's proposal? How could he simultaneously say that "every good citizen will be at once a centinel over the rights of the people; over the authorities of the [federal] government; and over both the rights and the authorities of the [state] governments," ${ }^{\prime \prime}$ while at the same time insisting that "appeals to the people" in the form of popular conventions were "neither a proper nor an effectual provision" for safeguarding constitutional limits? ${ }^{80}$

There is a simple answer to this seeming contradiction. What Madison objected to in Jefferson's proposal was not the principle it embodied, but the way it put that principle into action. Like Jefferson, Madison believed in popular control, believed that "the sense of the people" should decide what the government did and how the Constitution was interpreted. ${ }^{81}$ But Jefferson's approach looked for a kind of popular control that would not (and could not) work in practice because it was too unmediated and direct.

\footnotetext{
7614 PAPERS OF MADISON, supra note 14.

77 THE FEDERALIST No. 51, supra note 17, at 348; see supra note 47.

78 THE FEDERALIST NO. 49, supra note 69 , at 339, 343.

79 Madison, Government, supra note 18 , at 178.

80 THE FEDERALIST No. 49, supra note 69 , at 343.

81 See supra notes 47-52 and accompanying text; see also James Madison, A Candid State of Parties, NAT'L GAZETTE, Sept. 22, 1792, in 14 PAPERS OF MADISON, supra note 14, at 370-71 (true republicans are "naturally offended at every public measure that does not appeal to the understanding and to the general interest of the community"); James Madison, Consolidation, NAT'L GAZETTE, Dec. 3, 1791, in 14 PAPERS OF MADISON, supra note 14, at 137-38 (worrying that without state governments "neither the voice nor the sense" of the people "could ever be combined or called into effect"); Sheehan, Party Press, supra note 50, at 371-73.
} 
Valparaiso University Law Review, Vol. 41, No. 2 [2007], Art. 5

Among the lessons Madison took from his study of history was that popular government could succeed only if decision-making was mediated and refined through a system of accountable representatives. As he explained in Federalist 10, the critical distinction between pure democracies, which experience taught were short-lived "spectacles of turbulence and contention," and a well designed republic was precisely "the delegation of the Government, in the latter, to a small number of citizens elected by the rest." 82 A proper "scheme of representation," thus, "open[ed] a different prospect and promis[ed] the cure for which we are seeking." 83 It did not matter that a question was constitutional in nature: turning directly to "the whole society" for an immediate answer (which is how the Founding generation saw popular conventions) ${ }^{84}$ was perilous and unnecessary. Not because the public lacked the right to decide, and not because the public would never do so. The public's right to decide was, in fact, incontestable. But the experience of the ancients (as well as that of the Americans themselves) taught that a nation would all-too-quickly collapse if the public decided too directly, too often, and on too many things. Instead, a proper system of representation was needed: one that would, if carefully constructed, secure popular government while reducing the need for direct popular action, which could then be held in reserve for use only on, as Madison put it, "certain great and extraordinary occasions." 85

$$
* * *
$$

But how would this work? What, in other words, was Madison's representation-based alternative to Jefferson's direct popular constitutionalism? Having rejected Jefferson's approach, Madison went on to spell out his own version of popular constitutionalism in the very next essay, the famous Federalist 51.86

\footnotetext{
82 THE FEDERALIST No. 10, supra note 10, at 61-62.

$83 \quad$ Id. at 62.

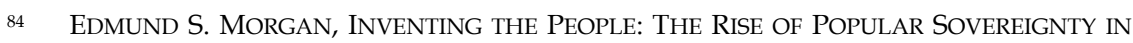
ENGLAND AND AMERICA (1988). People "ascribed to one set of elected representatives meeting in convention a more popular character, and consequently a greater authority, than every subsequent set of representatives meeting as a legislature." Id. at 91; see RAKOVE, ORIGINAL MEANINGS, supra note 8, at 93-102; WOOD, CREATION, supra note 9, at 306-10, 319, 328-43.

85 THE FEDERALIST NO. 49, supra note 69, at 339.

86 Placement alone might have suggested that these three essays have something to do with one another. Yet with a few notable exceptions (e.g., RAKOVE, ORIGINAL MEANINGS, supra note 8, at 280-82), commentators seem to have simply missed the connection. Typical discussions of Madison's ideas in The Federalist either ignore Federalists 49-50 or treat these essays as a puzzling detour from the analysis of separation of powers that Madison had begun in Federalists 47-48. See JAMES MADISON: THE THEORY AND PRACTICE OF REPUBLICAN GOVERNMENT (Samuel Kernell ed., 2003); RICHARD K. MATTHEWS, IF MEN WERE ANGELS: JAMES
} 
As we have just seen, Madison thought popular government could work only if politics were mediated through representative institutions. But representation was only a start and was not, by itself, sufficient. After all, the popular conventions championed by Jefferson consisted of representatives chosen by the people. More was necessary to refine and construct a public decision worthy of respect, and that more, Madison explained in Federalist 51, consisted of establishing multiple representative institutions within an enlarged polity and setting them in proper relation to one another. Or, in Madison's own words, "the defect must be supplied, by so contriving the interior structure of the government, as that its several constituent parts may, by their mutual relations, be the means of keeping each other in their proper places." 87 This meant, in particular, and as Madison explained in the remainder of Federalist 51, utilizing a bicameral legislature, an executive veto, federalism, and extensive size.

As with Federalists 49-50, we cannot accurately comprehend Madison's logic without first ridding ourselves of a widely shared misunderstanding. For few passages from The Federalist are more familiar than this one, and few have been more consistently and egregiously misread. Conventional wisdom tells us that Madison sought to preserve constitutional limits by devitalizing popular politics and creating a balanced equilibrium within the government, forming "a machine that would go of itself." 88 On this view, the Framers complicated the system by establishing separate branches and departments and then giving each a constitutional power to check or obstruct the others. Their hypothesis was that officials within the different institutions could be counted on to protect the powers and prerogatives of their respective offices. They would, as a result, reliably act in the ordinary course of governing to prevent rivals in the other branches from overreaching in violation of the Constitution. Constitutional scholars and political philosophers treat this strategy as nothing less than sheer genius. "[O]fficials would not have to be public-spirited," one commentator observes breathlessly, because "their self-interested defence of the power of

MADISON AND THE HEARTLESS EMPIRE OF REASON (1995); GARY ROSEN, AMERICAN COMPACT: JAMES MADISON AND THE PROBLEM OF Founding (1999); MORTON WHITE, PHILOSOPHY, THE FEDERALIST, AND THE CONSTITUTION (1987). This is, I believe, both a cause and an effect of the general misreading of Federalist 51 discussed below.

87 THE FEDERALIST NO. 51, supra note 17 , at 347-48.

88 The quote is from an 1888 speech by James Russell Lowell to the Reform Club of New York. MichaEl KAMMEN, A MACHINE THAT WOUld Go OF ITSElF: THE CONSTITUTION IN AMERICAN CULTURE 18 (1986); see Daryl Levinson, Empire-Building Government in Constitutional Law, 118 HARV. L. REV. 915, 950 (2005). 
Valparaiso University Law Review, Vol. 41, N0. 2 [2007], Art. 5

their offices would still contribute unintentionally to the maintenance of the constitutional balance." 89

The problem is that critical aspects of this reading of Federalist 51 do not sit well or even make particular sense. The argument turns, for instance, on the relevant institutions each having a constitutional power to block unconstitutional acts of the others. Yet while some of the devices Madison discussed fit this description, others do not. States have no constitutional power to block the federal government, not after the Supremacy Clause. So why mention federalism? And extensive size has nothing at all to do with interbranch or intergovernmental checking. Yet the discussion of these two features took up more than half of Federalist 51, while Madison breezed through bicameralism and the executive veto in a single paragraph.

More damning still, this interpretation of Federalist 51 rests on the implausible assumption that officeholders in different branches would make protecting the institutional prerogatives of their respective offices a priority. Even without political parties, why would anyone expect legislators to object to Presidential action they agreed with and supported? Why assume that state governments would oppose federal legislation that did what the states wanted? As Daryl Levinson has recently pointed out, politicians must normally be expected to put political concerns above institutional ones. ${ }^{90}$ Not always, of course, and we do occasionally see an institution act to protect itself contrary to the immediate political interests of its members. But this is unusual, and that was as true in 1788 as it is today. No thoughtful politician or careful student of politics - and Madison was both - could possibly have thought otherwise.

It is unlikely, to say the least, that Madison would have built his whole theory around such a farfetched proposition. And, sure enough, the language of Federalist 51 supports a different and more sensible reading. In explaining his argument, Madison says that "the great security . . consists in giving those who administer each department, the necessary constitutional means, and personal motives, to resist encroachments of the others. ... Ambition must be made to counteract ambition. The interest of the man must be connected with the constitutional rights of the place." ${ }^{91}$ We can presume, I think, that Madison understood perfectly well that the "personal motives" and "interests" of elected officials would be political motives and political interests - in other words, that officials would have political agendas they were seeking to advance, agendas that were

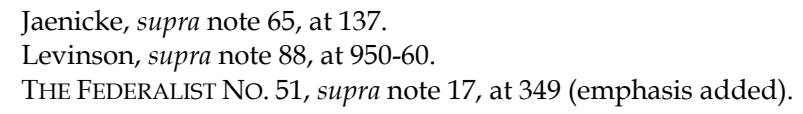


responses to the desires and beliefs of their constituents. The key to making the Constitution work lay in finding a way to harness these political interests, and the power to advance them by using constitutional authority granted to the institutions in which the officials worked, for the benefit of constitutional enforcement.

If this is right, and I think it must be, it suggests revisiting the prevailing understanding of Madison's theory of constitutional enforcement, as well as his broader theory of deliberative democracy, both of which rest heavily on this (mis)reading of Federalist 51. We should do so, moreover, by looking comprehensively at what Madison said and did during the Founding period, reading what he wrote as Publius not in isolation, but rather against the background of his earlier and later actions and in conjunction with his writings of the early 1790s. And when we do that, a very different Madison emerges, with a very different theory of deliberative democracy and popular constitutionalism.

As we have seen, Madison began from the conviction that a government is republican only if and to the extent that its actions are guided and controlled by public opinion. If I seem to be making this point a lot, that's because I am: because it has been so widely neglected, and because its importance as Madison's first principle cannot be overstated. ${ }^{92}$ Establishing a republican government, the cause to which Madison dedicated his life and the object toward which all his thinking was directed, meant establishing "a Government of opinion." 93

This concept of opinion requires a bit of elaboration and some qualification. To begin with, when Madison spoke of public opinion he did not have something abstract or imaginary in mind. Modern political philosophers have tended to flatten the idea of popular sovereignty, to treat it as a disembodied or purely notional justification for government. Not so Madison. He understood public opinion to be "an operationally active and authoritative sovereign," reflecting definite views or positions on public

92 As will become obvious, my discussion here owes a great intellectual debt to Colleen Sheehan, who has, almost singly and for more than fifteen years, argued that we misread Madison by paying too little attention to his writings of the 1790s and his emphasis on popular opinion. See Sheehan, Public Opinion, supra note 51; Sheehan, Party Press, supra note 50; Sheehan, Civic Character, supra note 54; Sheehan, Politics of Public Opinion, supra note 55.

93 Letter from James Madison to Edward Livingston (July 10, 1822), in 3 LETTERS AND OTHER WRITINGS OF JAMES MADISON 265 (Philip R. Fendall ed., 1865) [hereinafter LETTERS OF MADISON]. 
Valparaiso University Law Review, Vol. 41, No. 2 [2007], Art. 5

affairs that had been given concrete expression by the people themselves. ${ }^{94}$ This is why he saw ignoring public opinion as counterrevolutionary, and why he insisted that true republicans were "naturally offended at every public measure that does not appeal to the understanding and to the general interest of the community." 95 In concrete terms, respect for opinion required elected officials to run their ideas past constituents and let the public's reactions determine what the government did.

There is, of course, an important sense in which this sort of public control is inescapable. Government must have the community's acquiescence, if not active support, and no regime can survive if it continuously negates popular will. That was Hume's point about how even the most "despotic" and "military" governments ultimately "have nothing to support them but opinion." 96 Certainly Madison believed this, ${ }^{97}$ as did his political opponents. But they drew very different conclusions from it.

For Federalists, who wanted government lodged safely in the hands of gentlemen like themselves, the lesson was to dampen popular politics: to de-politicize public life to the extent possible, and by doing so to foster passive acceptance of government action. Federalists believed in republicanism, but saw themselves as clear-eyed pragmatists with no illusions about the capacity of ordinary citizens to make "disinterested" or "virtuous" judgments about policy. Popular rule needed to be trammeled and hedged in order to ensure that decisions were made only by the most competent and qualified. Making government remote was one way to achieve this, which is why Federalists preferred national to state power. It is also why they condemned anything that smacked of popular mobilization, and why they relentlessly propagandized the need for submission, obedience, and deference. ${ }^{98}$

\footnotetext{
94 Sheehan, Public Opinion, supra note 51, at 948; Sheehan, Politics of Public Opinion, supra note 55, at 619; see also KRAMER, THE PEOPLE THEMSELVES, supra note 1, at 3-8.

95 James Madison, A Candid State of Parties, NAT'L GAZETTE, Sept. 22, 1792, in 14 PAPERS OF MADISON, supra note 14 , at $370-71$.

96 HUME, supra note 54.

97 See Madison, Charters, supra note 60, at 191-92. "All power has been traced up to opinion. The stability of all governments and security of all rights may be traced to the same source. The most arbitrary government is controuled where the public opinion is fixed. The despot of Constantinople dares not lay a new tax, because every slave thinks he ought not." Id.

98 In essence, Federalists wanted a monarchical social order without a monarch and with an aristocracy based on wealth and accomplishment rather than birth. Elections were fine, but only so long as these remained (as they were in England and had been in America) contests among gentlemen, whose purpose and effect was to shore up conventional patterns of deference by requiring notables to spend a few days "familiariz[ing]" themselves through personal solicitation or by "tak[ing] a chearful cup" with ordinary folk. 2 THE DIARY OF
} 
Because of his brief alliance with those who held such views, Madison has long been treated as sharing their philosophy and objectives, at least during the period of common partnership in the 1780s. And clearly there were areas of agreement. Madison was perhaps the foremost advocate of using national power to check state politics, and Federalist 10 shows how he also believed that government leadership should be in the hands of an elite. But Madison had his own, very different reasons for taking these positions, as we shall see in a moment. What agreements existed in the 1780 s between him and people like Hamilton, Wilson, and Gouverneur Morris turned out to be on tactics and to have obscured profound differences in philosophy. Madison's beliefs were, indeed, very nearly the opposite of theirs. He thought public opinion should control what government did, and he held that creating a republican government meant embracing and maximizing public control, not acting to pacify or divert it. To Madison's way of thinking, the inevitability of popular control gave rise to a corresponding responsibility to refine and improve public deliberations, so as to ensure that the sovereign, controlling public opinion was also reasonable and just.

This last point is crucial, as it draws attention to an important normative qualification in Madison's thinking about opinion. On the one hand, Madison recognized that the will of the majority must rule. "In republican Government," he wrote in his memo on Vices of the Political System of the United States, "the majority however composed, ultimately give the law." 99 This was, indeed, "the fundamental principle of republican Government." 100 On the other hand, a government could be republican and still be unjust, tyrannical, and not worth serving or preserving. Madison had not dedicated his life to the cause of republicanism without regard for its quality or content. A republican government could be more just, but only

LANDON CARTER, 1752-1778, at 1008-09 (Jack P. Greene ed., 1965) (confessing he was turned out of office for failing to "familiarize myself among the People"); see also ROBERT MUNFORD, THE CANDIDATES; OR, THE HUMOURS OF A VIRGINIA ELECTION 34 (Wm. \& Mary 1949) (1770) (Sir John Toddy is liked by plain folk in this farce because he "wont turn his back upon a poor man, but will take a chearful cup with one as well as another."). An analogy between eighteenthcentury elections and medieval carnival, characterized by a temporary upending of normal social relations in order to reinforce them, is made in MORGAN, supra note 84, at 174-208, and in Andrew W. Robertson, Voting Rites Revisited: Electioneering Ritual, 1790-1820, in BEYOND THE FOUNDERS: NeW APPROACHES TO THE POLITICAL HISTORY OF THE EARLY AMERICAN REPUBLIC (Jeffrey L. Pasley, Andrew W. Robertson \& David Waldstreicher eds., 2004). As Gordon Wood has observed, Federalists believed in democracy, "but not our modern democracy; rather, they believed in a patrician-led classical democracy in which 'virtue exemplified in government will diffuse its salutary influence though the society.'” Wood, Interests and Disinterestedness, supra note 8 , at 83

99 James Madison, Vices of the Political System of the United States, in 9 PAPERS OF MADISON, supra note 14, at 348, 355 [hereinafter Madison, Vices of the Political System].

$100 \quad$ Id. at 354. 
if the majority that ruled did not itself become despotic or tyrannical. And the lesson of the 1780s was that this might not be easy and certainly could not be taken for granted. So while republicanism meant subjecting "the will of the government to the will of the society" (meaning the will of the majority), that alone was not enough. It was necessary also to subject "the will of the society to the reason of the society." 101

In affirming the authority of public opinion, in other words, Madison was preaching majority rule but not simple majoritarianism. Majority opinion would hold sway, but the majority opinion that should hold sway had to be more than the fleeting passions or preferences of the moment, more than the unreflective reactions of a transient majority of citizens. Colleen Sheehan explains:

Madison did not simply equate public opinion with the will of the majority. Public opinion [was] not the sum of ephemeral passions and narrow interests; it [was] not an aggregate of uninformed minds and wills. Rather, public opinion require[d] the refinement and transformation of the views, sentiments, and interests of the citizens into a public mind guided by the precepts of reason, resulting in 'the reason .... of the public' or 'the reason of the society.' ${ }^{102}$

This was Jefferson's point when he urged in his first inaugural address that Americans "bear in mind this sacred principle, that though the will of the majority is in all cases to prevail, that will to be rightful must be reasonable." 103

$$
* * *
$$

Ensuring that the will of the majority was reasonable was, in the first instance, a responsibility of leadership. Those whose situation in life had afforded them the opportunity to elevate their minds had a corresponding obligation to elevate those of their fellow citizens, particularly on matters of politics and government. "The class of the literati," Madison wrote in notes to himself, "are the cultivators of the human mind - the manufacturers of useful knowledge - the agents of the commerce of ideas, - the censors of

\footnotetext{
101 James Madison, Universal Peace, NAT'L GAZETTE, Jan. 31, 1792, in 14 PAPERS OF MADISON, supra note 14, at 206-07.

102 Sheehan, Public Opinion, supra note 51, at 948.

103 Id. The quote can be found in Thomas Jefferson, First Inaugural Address (Mar. 4, 1801), in 1 A COMPILATION OF THE MESSAGES AND PAPERS OF THE PRESIDENTS 321, 322-23 (J. Richardson ed., 1897).
} 
public manners - the teachers of the arts of life and the means of happiness." 104 It was the task of this elite to educate and edify, to foster a process of deliberation that refined and enlightened public sentiment in a fashion sufficient for the demands of self-government.

This responsibility lay particularly on elected officials. We have already noted how Madison reserved a role for government in helping to shape public opinion where it was "not ... fixed."105 We now see why. As Colleen Sheehan notes, precisely because public opinion is sovereign, "the republican statesman is obliged to advance its formation and expression."106 It was with this in mind, for instance, that Madison emphasized how critical "Representatives going from, and returning among every part" of the nation were to securing republican liberty a safeguard whose importance, he said, was matched only by "a circulation of newspapers through the entire body of the people."107 Representatives traveling to and from the seat of government acted as "agents for the exchange of political ideas among the citizenry. As elected officials whose task was to deliberate on issues of national import, they [could] both attend to the views of their constituents and convey back to them the concerns and interests of the nation at large." 108

This sort of educative leadership would be effective, however, only if proper leaders were in place. Hence Madison's excitement when he realized how a large republic could foster "a process of elections as will most certainly extract from the mass of the Society the purest and noblest characters which it contains."109 Madison's objective was not to select an elite that would deliberate for the public; nor was it to place this elite at such a remove from the people that it could work free from their interference. Rather, Madison wanted "the ablest Statesmen \& soundest Republicans" to

\footnotetext{
104 Notes for the National Gazette Essays, in 14 PAPERS OF MADISON, supra note 14, at 157, 168.

105 See supra notes 56-58 and accompanying text (quoting Madison, Public Opinion, supra note 53, at 170) (while public opinion must be obeyed once it has settled, "where not . . . fixed, it may be influenced by the government").

106 Sheehan, Politics on Public Opinion, supra note 55, at 620.

107 Madison, Public Opinion, supra note 53, at 170. Alongside these devices Madison also listed "good roads, domestic commerce, [and] a free press," that is, "[w] hatever facilitates a general intercourse of sentiments" among the people. Id.

108 Sheehan, Public Opinion, supra note 51, at 953.

109 Madison, Vices of the Political System, supra note 99, at 357. As Madison explained the same point in Federalist 10, size would make it "more difficult for unworthy candidates to practice with success the vicious arts, by which elections are too often carried" and so result "in the substitution of Representatives, whose enlightened views and virtuous sentiments render them superior to local [views], and to schemes of injustice." THE FEDERALIST NO. 10, supra note 10 , at 64 .
} 
Valparaiso University Law Review, Vol. 41, No. 2 [2007], Art. 5

seek positions of leadership so they could teach and inform the public, elevating the discussion, fending off local prejudices, and improving the citizens' minds and morals. ${ }^{110}$ Those in office, whoever they were, would necessarily know more about public affairs than ordinary citizens. It would be their job to know and would be what they spent their time learning about. Public officials were, as a result, in the best position to provide the kind of civic education that was essential to guide the public's thinking. To play their part well, however, these public officials needed to be the sorts of people who would use their superior knowledge and position to move public opinion in the direction of reason, moderation, and justice.

The political process Madison imagined was thus dramatically different from the sort of deferential politics that Federalists wanted (and that Madison has often erroneously been thought to have favored). ${ }^{111}$ "Symbolically," explains historian Christopher Grasso, "the 'public' came to be seen, not as a body ruled by a sovereign head, but as a mind that ruled itself." 112 This did not mean the flattening or elimination of all distinctions; neither Madison, nor Jefferson, nor anyone else then alive was quite so modern. But it did embody a profound, if subtle, shift in the nature of politics. At the risk of oversimplifying, one can describe the general direction of change as follows: Where Federalists emphasized the power and patronage of a wealthy gentry whose superior virtue deserved submission, Madison's politics are better characterized as a conversation, a conversation in which the elite now led by persuasion an electorate actively engaged in making its own judgments and decisions.

The extended republic served a second critical purpose in Madison's scheme, one that helps explain why, having laid the argument out in Federalist 10, he included it again in Federalist 51. ${ }^{113}$ Generating reasonable and reasoned public opinions would take time and would require a proper forum for deliberation. This was difficult to achieve in a small republic, where the limited range of competing interests made forming a factious majority too easy. Virtuous leaders could, in theory, block this from happening, but in practice one could not depend on it:

110 See Jack N. Rakove, The Structure of Politics at the Accession of George Washington, in BEYOND CONFEDERATION, supra note 8 , at 261, 271. The quote is from Letter from James Madison to Caleb Wallace (Aug. 23, 1785), in 8 PAPERS OF MADISON, supra note 14, at 350, 354.

111 See authorities cited supra note 8.

112 CHRISTOPHER GRASSO, A SPEAKING ARISTOCRACY: TRANSFORMING PUBLIC DISCOURSE IN EIGHTEENTH-CENTURY CONNECTICUT 282, 448-51 (1999).

113 THE FEDERALIST No. 51, supra note 17, at 351-53. 
It is vain to say, that enlightened statesmen will be able to adjust these clashing interests, and render them all subservient to the public good. Enlightened statesmen will not always be at the helm: Nor, in many cases, can such an adjustment be made at all, without taking into view indirect and remote considerations, which will rarely prevail over the immediate interest which one party may find in disregarding the rights of another, or the good of the whole. ${ }^{114}$

Added safeguards were needed to blunt the process of majority formation: to slow it down long enough to give government officials and other members of the "literati" an opportunity to lead a proper public debate. And among the surest of these additional safeguards was simply to make the republic larger:

Extend the sphere, and you take in a greater variety of parties and interests; you make it less probable that a majority of the whole will have a common motive to invade the rights of other citizens; or if such a common motive exists, it will be more difficult for all who feel it to discover their own strength, and to act in unison with each other. ${ }^{115}$

The difficulty of forming such majorities would, in turn, create time and space for the kind of public debate and discussion that was necessary to refine popular opinion and help it coalesce around a just decision.

Note how this description of the effects of enlarging a republic differs from the usual understanding of Madison's famous argument. The usual assumption is that, because Madison feared that legislators would be too responsive to majorities, he wanted to prevent majorities from forming, thereby leaving officials free to craft solutions that satisfied an independent and objective notion of "the public good." But, as we have seen, Madison was committed to the idea of majority rule and believed in the sovereignty of public opinion. His actual concern was more focused. It was not majorities that Madison feared. It was unreflective, factious majorities: the kind of majorities that he thought could be formed all too easily and all too quickly at the state level. The benefit of extensive size was that, by making it more difficult for majorities to form, a large republic gave reasoned argument an opportunity to prevail, so that whatever "coalition of a

114 THE FEDERALIST No. 10, supra note 10, at 61.

115 Id. at 64. 
Valparaiso University Law Review, Vol. 41, No. 2 [2007], Art. 5

majority of the whole society" eventually emerged "could seldom take place on any other principles than those of justice and the general good."116

Yet this still was not enough. For it was dangerous, even in a large republic, to entrust the role of collecting and acting on public opinion to a small, concentrated set of individuals. There is, after all, the risk we noted above that "enlightened statesmen will not always be at the helm." And even if voters did manage to elect only "the most diffusive and established characters," 117 these representatives would regularly face vexing problems that lacked determinate solutions, for the Constitution was obscure and imprecise in important respects. ${ }^{118}$ Given such risks and such problems, it was not enough just to elect representatives, even in an extended territory. "The genius of Republican liberty" demanded as well that "the trust should be placed not in a few, but in a number of hands."119

By "number of hands," Madison did not mean a big government, though he did believe that "the Representatives must be raised to a certain number, in order to guard against the cabals of a few." 120 More precisely, Madison meant a complicated government: a government that provided "double security ... to the rights of the people" because its powers were "first divided between two distinct governments, and then the portion allotted to each, subdivided among distinct and separate departments."121 Structural innovations in the form of federalism and separation of powers

\footnotetext{
116 THE FEDERALIST NO. 51, supra note 17, at 353.

117 THE FEDERALIST No. 10, supra note 10, at 63.

118 See THE FEDERALIST No. 37, at 231-39 (James Madison) (Jacob E. Cooke ed., 1961). In this wonderful and underappreciated essay, Madison lays out the many causes of textual indeterminacy, including the difficulty of balancing "energy" and liberty, the complexity of drawing a line between state and federal power, the impossibility of defining the powers and divisions of government given the state of the "science of Government" and limitations in the use of language, the "interfering pretensions of the larger and smaller States," and the resulting need to compromise. THE FEDERALIST NO. 37, supra note 118, at 235, 237. An excellent analysis may be found in RAKOVE, ORIGINAL MEANINGS, supra note 8, at 156-60.

119 THE FEDERALIST NO. 37, supra note 118, at 234.

120 THE FEDERALIST No.10, supra note 10, at 62-63. Madison's views on the proper size of the legislature were complex: there needed to be enough representatives to make corruption difficult, but not so many as to make governing impossible; and, in all events, the ratio of representatives to constituents needed to be balanced. For an analysis, see BANNING, supra note 51 , at $195-233$.

121 THE FEDERALIST No. 51, supra note 17, at 351; see also Madison, Charters, supra note 60, at 191-92 (arguing that the people of the United States have a special responsibility to maintain their constitutions given "[t]he complicated form of their political system, arising from the partition of government between the states and the union, and from the separations and subdivisions of the several departments in each ....").
} 
thus became the final elements of Madison's theory, indispensable because they provided the means to make the "personal motives" and political interests of elected officials work to advance the cause of republican liberty and popular constitutionalism.

The idea, once understood, is really quite ingenious. We complicate the government by creating several levels, each with multiple branches or departments. All the departments at each level are then made accountable to the people. (Not courts, of course: the judiciary was intentionally designed to be unaccountable. But courts were not a significant player in Madison's thinking about constitutional enforcement in the 1780s, which is why they have no role in Federalist 51 and make only cameo appearances in his other essays.122 I will come back to courts below, because they were eventually assigned a part. For now, the point to recognize is that Madison's original theory of constitutional enforcement was political in nature, and the "departments" Madison had in mind when he wrote about separation of powers were the House, the Senate, and the Executive, that is, the branches of government whose members were popularly accountable.)

Accountable, to be sure, but in different ways and to different constituencies within the larger national polity. Members of the House of Representatives were directly accountable, for instance, but to small constituencies relative to the other branches. Members of the Senate were accountable to larger state-wide constituencies, but only indirectly. The President was still more indirectly accountable, but in his case to the nation as a whole. It was similar at the state level: most of the states likewise had bicameral legislatures with each house chosen under a different scheme of representation, and all the states picked their executives by more or less indirect means; some states also had independently elected executive councils, again chosen by various means. ${ }^{123}$

These differences in how officials were chosen and to whom they were accountable mattered, because they meant that members of the different governments and of different departments within these governments would have different political interests and agendas. This would be true, moreover, no matter how public officers conceived their roles. Perhaps they would put their energy into serving some notion of "the public good," or maybe they would back whichever measures maximized their chances for reelection. Or, more realistically, they might do a bit of both. It actually

122 See supra notes 14-15 and accompanying text.

123 Madison discussed differences among the states in THE FEDERALIST NO. 47, at 327-31 (James Madison) (Jacob E. Cooke ed., 1961). For a somewhat more systematic survey, see Willi PAUl ADAMS, THE FIRST AMERICAN CONSTITUTIONS app., at 315-31 (2001). 
Valparaiso University Law Review, Vol. 41, N0. 2 [2007], Art. 5

would not matter. For however elected officials approached their jobs, their perceptions of what the public wanted or needed, or of what furthered their political careers, would necessarily be shaped by the different situations in which they found themselves by virtue of the location and structure of their office. By then assigning the different offices ways to block or obstruct each other, these varied and various perspectives, with their "opposite and rival interests," could be used to supply "the defect of better motives" in safeguarding the Constitution by securing the sovereignty of public opinion.

How would it work? Suppose the President takes some action, say, unilaterally declaring U.S. neutrality in a war between England and France, or initiating a plan to wiretap American citizens without first obtaining warrants. If that action is contrary to the political interests of actors in any part of the system, and a plausible constitutional objection exists or could be made, we can expect to see the issue raised. If, therefore, no one anywhere in this complex system objects, we have about as good an assurance as we can ever realistically hope to get that there is no plausible objection.

Obviously, that's not certain; no system is infallible or completely foolproof. One can in theory imagine actions that are unconstitutional but serve the interests of elected officials at every level and in every department. Or there could be times when potential objectors are not paying attention, or where the stakes for everyone are simply too low to matter. But with so many different institutions, staffed by politicians with so many different potential interests to motivate them, universal acquiescence may be the best possible vote of confidence we can generate.

Conversely, if there is a potential objection, we should expect to see the issue raised by someone in this complex system, and we should expect that someone to use or attempt to use the powers of his or her office to block or obstruct the action in question. This will not end the matter, even if successful. Nor is it supposed to do so. For the use of a constitutional check is not meant to conclude a dispute. It is meant to begin one: to force the kind of public debate needed for "the reason of the society" to emerge and coalesce.

To illustrate, suppose the House debates a bill and concludes that a proposed law reflects good policy and is also constitutional. A majority of the Senate disagrees: they do not like the law, and they believe it unconstitutional for some reason. They refuse to pass it. What happens next? The bill may die, as perhaps it should if members of the House give the law a low priority or have no answer to the Senate's objections. But if 
they care and have an argument to support their position, the Senate's refusal to act should arouse a response. Recall Madison's admonition about the importance of representatives "going from, and returning among every part of [the people]."124 Madison assumed that members of the House who supported the bill would go back to their constituents and argue that the Senate was wrong, that the law was both useful and constitutional and that voters needed to put pressure on the Senate to relent. Senators, in the meantime, were not expected to sit idly by. They were supposed to do the same thing: return home, give speeches, write editorials, and make their case that the law was undesirable or unconstitutional. And so we would have a genuine public debate in which, eventually, the community would settle on a view, at which point the political pressure brought to bear would force the losing branch to yield.

Even this might not end the matter. Suppose, for example, that public opinion led the Senate to succumb. There might still be objections from the President, who could exercise a veto, or from politicians in the states, who had at their disposal a variety of devices politically to challenge federal law (devices Madison fleshed out in Federalists 45-46). In either case, the debate would then continue to whatever end the public eventually embraced. And in this way, separation of powers and federalism became instrumentalities for generating a robust public discussion, initiated and led by political leaders acting for their own reasons, through which the "reason of the society" could be developed and "the people themselves" retain control.

This, I believe, is what Madison had in mind when he spoke of connecting the "interest of the man" with "the constitutional rights of the place." 125 This is how "[a]mbition [could] be made to counteract ambition"126 to ensure compliance with the Constitution. But the compliance we get, and the compliance Madison sought, is compliance with the Constitution as understood by the sole, final arbiter of its meaning, "the people themselves; who, as the grantors of the commission, can alone declare its true meaning, and enforce its observance." 127

Note how the people's control, while real and substantial, is not direct. It is indirect: mediated through popular responses to arguments and to the action or inaction of representatives in different parts of different governments, representatives who are in turn taking their cues from the

\footnotetext{
124 See supra note 107 and accompanying text (quoting Madison, Public Opinion, supra note 53, at 170).

125 THE FEDERALIST No. 51, supra note 17, at 349.

$126 \quad I d$.

127 THE FEDERALIST No. 49, supra note 69, at 339.
} 
Valparaiso University Law Review, Vol. 41, N 0.2 [2007], Art. 5

public. It is, nevertheless, genuine popular control, a system of constitutional regulation that avoids the pitfalls of Jefferson's direct popular constitutionalism without betraying the basic commitment to republicanism. ${ }^{128}$

And now, finally, what about courts? As already noted, judges were for the most part left out of Madison's original scheme for interpreting and enforcing the Constitution. At the Philadelphia Convention, he grudgingly conceded the judiciary a role mediating boundary disputes between the national government and the states, though with little enthusiasm and low expectations for their efficacy. ${ }^{129}$ More telling, he ignored courts entirely when it came to separation of powers. The process Madison envisioned and found attractive was meant to be played out amongst the government's politically accountable branches and between those branches and the community. This made sense even apart from concerns about republicanism, since nothing in history or experience suggested that courts could or would, much less should, be an important factor in enforcing a

128 This description will hopefully clarify the relationship between popular constitutionalism and direct popular action. Popular constitutionalism does not depend on popular action targeted against the government, such as the mobs of colonial America, though it may be responsive to such action. It is, however, mainly concerned with popular action that seeks to work through the government, whether in the form of a social movement, a political party, the myriad private associations of civil society, or elected representatives' responses to the general moods and dispositions of voters. Popular constitutionalism is found in the relationship between the formal agencies of government and the citizens these agencies seek to serve. It is open to popular movements in any and all forms, requiring only that these movements seek to achieve their ends under the Constitution in the form of official action of some sort (laws, constitutional amendments, executive action, even judicial decisions). Its energy and ideas often, though not always, come from outside the state's formal organs, but it depends on these organs to test and mediate and give form to the demands of citizens. Popular constitutionalism is, as a result, fluid: as fluid as politics itself.

129 Compare THE FEDERALIST No. 39, at 256 (James Madison) (Jacob E. Cooke ed., 1961) (the tribunal which is to decide "is to be established under the general Government"), with THE FEDERALIST NOS. 45-46, at 308-323 (James Madison) (Jacob E. Cooke ed., 1961) (describing how states can protect themselves from federal overreaching), and Letter from Madison to Jefferson, in 10 PAPERS OF MADISON, supra note 14, at 206, 211 (complaining how reliance on the judiciary will not work). As is well known, Madison wanted to control the states through a congressional negative on state laws. The Supremacy Clause was offered and accepted at the Philadelphia Convention only after this proposal was defeated, put forth by states' rights advocate Luther Martin precisely because it was so weak, which is also why no similar effort was made explicitly to endorse judicial review of federal legislation. KRAMER, THE PEOPLE THEMSELVES, supra note 1, at 74-76. As Madison's letter to Jefferson indicates, this decision thoroughly discouraged him, though of course he made the best he could of it in defending the document that ultimately emerged. 
constitution. (Consider in this regard that the phrase "constitutional law" did not yet exist and would not come into use before the 1790s.) ${ }^{130}$

Madison supported an independent judiciary, of course, like most others at the time. ${ }^{131}$ But also like most others, he did so for reasons having nothing to do with constitutional enforcement. Instead, he saw the need for independence chiefly through the lens of British and colonial experience, which had no doctrine of judicial review, ${ }^{132}$ but which taught that judges needed tenure and salary protection to immunize them from being influenced by the more powerful political branches in ordinary civil and criminal cases. ${ }^{133}$ To avoid this, Madison advised his friend Caleb Wallace,

130 DANIEL HULSEBOSCH, CONSTITUTING EMPIRE: NEW YORK AND THE TRANSFORMATION OF CONSTITUTIONALISM IN THE ATLANTIC WORLD, 1664-1830, at 255 (2005).

131 See Gerhard Casper, The Judiciary Act of 1789 and Judicial Independence, in ORIGINS OF THE FEDERAL Judiciary 281 (Maeva Marcus ed., 1992). As Casper explains, support for "independence" was well nigh universal, but its definition and the problem of balancing independence with accountability in a republican system produced widespread disagreement and confusion.

132 Courts had almost no role enforcing the British and colonial customary constitutions, which recognized nothing like judicial review, an idea that appeared only in the early 1780s. See KRAMER, THE PEOPLE THEMSELVES, supra note 1, at 18-24.

133 As I explained at length in The People Themselves, although a handful of sophisticated lawyers developed a doctrine of judicial review in the 1780s, the practice had not yet achieved widespread notice or approbation when the Constitution was written and ratified. The vast majority of Americans, including most politicians and political leaders, had never encountered judicial review, and most of the few who had encountered it seem to have been opposed. See $i d$. at 39-92. During ratification, the need for judicial independence was discussed constantly, but almost always in connection with the ordinary administration of justice. For just a few of countless examples that could be cited, see A Federal Republican: A Review of the Constitution (Nov. 28, 1787), in 14 THE DOCUMENTARY HISTORY OF THE RATIFICATION OF THE CONSTITUTION 255, 267-68 (John P. Kaminksi \& Merrill Saladino eds., 1983) [hereinafter DocUMENTARY HISTORY]; Federal Farmer: An Additional Number of Letters to the Republican (May 2, 1788), in 17 DOCUMENTARY HISTORY, supra, at 265, 335; Letter from Edmund Pendleton to Richard Henry Lee (June 14, 1788), in 18 DOCUMENTARY HISTORY, supra, at 178, 181; Letter from Richard Henry Lee to Edmund Randolph, Petersburg VA. GAZETTE (Dec. 6, 1787), in 14 Documentary HISTORY, supra, at 364, 371; PA. GAZETTE (Sept. 26, 1787), in 13 DOCUMENTARY HISTORY, supra, at 253; West-Chester Farmer: To the Citizens of America (June 8, 1787), in 13 DOCUMENTARY HISTORY, supra, at 129. Lawyers and historians today have inflated the importance of judicial review at the founding by focusing intensely on a handful of remarks that appear significant only in retrospect, failing to note how these comments went unnoticed and were practically unnoticeable in the context of the actual debate. The attention lavished on Brutus's three essays on the judiciary and on Hamilton's Federalist 78 illustrate this pathology. The exchange between these two essayists is quite sophisticated, and it makes for great reading. But Brutus's essays were reprinted nowhere and were essentially invisible, while Federalist 78 was published only in book form too late to influence any ratifying convention except (possibly) that of New York (where the question of judicial review never came up). KRAMER, THE PEOPLE THEMSELVES, supra note 1 , at 81 \& nn.43-45. Writing in 1804, Alexander Contee Hanson accurately noted that "the Federalist was not completed until almost every state in the Union had decided on the constitution; and therefore, be its excellence what it may, it could have had little weight in recommending the constitution." Editors' Note to Aristedes: Remarks on the 
Valparaiso University Law Review, Vol. 41, No. 2 [2007], Art. 5

that the judicial department "merits every care. Its efficacy [from being independent] is Demonstrated in G. Brittain where it maintains private Right against all the corruptions of the two other departments \& gives a reputation to the whole Government which it is not in itself entitled to."134

Madison wrote this letter to Wallace in 1785 . He did not mention judicial review, though he was already familiar with the doctrine, which had just recently begun to emerge in the states. Indeed, one of the earliest discussions of this newfangled idea arose in a Virginia case, Commonwealth v. Caton, ${ }^{135}$ decided in 1782 . The case achieved a degree of notoriety in the state and was quite controversial, though only two of eight judges argued that courts could review legislation. ${ }^{136}$ But letters and editorials in the newspapers fiercely debated what some referred to as " $[t]$ he great constitutional question," 137 and James Monroe can be found telling Madison as late as 1788 that the Virginia legislature had avoided discussing judicial review as something "calculated to create heats \& animosities that will produce harm." 138

Though controversial at first, the idea continued to gain support, slowly in the beginning, then more rapidly after the Constitution was ratified and went into effect. ${ }^{139}$ A variety of factors help to explain this acceptance, but in part it was simply that the argument for review in its original, modest guise was persuasive and hard to ignore. If the Constitution was supreme law, as everyone agreed that it was, then legislative acts contravening its terms were ultra vires and void: not law at all. Judges before whom such acts were brought in the course of ordinary litigation could not just ignore this fact. To do so would be to ignore a direct command from "the people" and abet another branch's violation of the people's expressed will. The

Proposed Plan of a Federal Government, in 15 DOCUMENTARY HISTORY, supra, at 517, 521. Despite this, commentators continue to make the same mistake of treating arguments that were marginal as if they were dominant or representative.

134 Letter from James Madison to Caleb Wallace (Aug. 23, 1785), in 8 PAPERS OF MADISON, supra note 14 , at 350 .

135 Commonwealth v. Caton, 8 Va. (4 Call) 5, 8 (1782).

136 See William Michael Treanor, The Case of the Prisoners and the Origins of Judicial Review, 143 U. PA. L. REv. 491, 500-40 (1995). George Wythe and James Mercer wrote in support; Peter Lyons was opposed and five others were undecided or unwilling to address a question that was unnecessary to decide the merits.

137 See Letter from Edmund Pendleton to James Madison (Nov. 8, 1782), in 5 PAPERS OF MADISON, supra note 14, at 260-61 (describing the resolution of " $\mathrm{t}]$ he great constitutional question, as it was called in our papers"); Treanor, supra note 136, at 504-05.

138 Letter from James Monroe to James Madison (Nov. 22, 1788), in 1 THE WRITINGS OF JAMES MONROE 196 (Stanislaus Murray Hamilton, ed., 1898).

139 This paragraph simplifies what was, in fact, a quite complicated set of developments. These are elaborated in detail in KRAMER, THE PEOPLE THEMSELVES, supra note 1, at 35-65. 
principle of popular sovereignty, the foundation on which the Constitution and government were supposed to rest, demanded that courts treat such laws as the nullities they were by refusing to enforce them.

Madison was of course willing to allow this much, and he acknowledged during the 1789 debate over the President's removal power that "in the ordinary course of government ... the exposition of the laws and constitution devolves upon the judicial." 140 But, he immediately added, this did not mean that judicial decisions had any special stature or status:

I beg to know, upon what principle it can be contended, that any one department draws from the constitution greater powers than another, in marking out the limits of the powers of the several departments. The constitution is the charter of the people to the government; it specifies certain great powers as absolutely granted, and marks out the departments to exercise them. If the constitutional boundary of either be brought into question, I do not see that any one of these independent departments has more right than another to declare their sentiments on that point. ${ }^{141}$

Thomas Jefferson, who embraced the same theory throughout his political life, ${ }^{142}$ expressed the idea succinctly: "[E]ach of the three departments has equally the right to decide for itself what is its duty under the constitution,

\footnotetext{
140 James Madison, Speech to the House of Representatives on the Removal Power of the President (June 17, 1789), in 12 PAPERS OF MADISON, supra note 14, at 232, 238.

141 Id.

142 See DAVID N. MAYER, THE CONSTITUTIONAL THOUGHT OF THOMASJEFFERSON 257-94 (1994). As Mayer explains, Jefferson's emphasis shifted over time, from an early confidence in the reliability of courts to a late-life belief that federal judges were an irresponsible "corps of sappers and miners" working to undermine the Constitution's careful balancing act. Letter from Thomas Jefferson to Thomas Ritchie (Dec. 25, 1820), in 10 THE WRITINGS OF THOMAS JEFFERSON 169-70 (Paul Leicester Ford ed., 1898). But these were changes in tone that occurred within the same departmentalist framework, a framework Jefferson restated on numerous occasions over the course of three decades. See Letter from Thomas Jefferson to George Hay (June 2, 1807), in 4 MEMOIRS, CORRESPONDENCE AND MISCELLANIES FROM THE PAPERS OF THOMAS JEFFERSON 75 (Thomas Jefferson Randolph ed., 1829) [hereinafter MEMOIRS OF JEFFERSON]; Letter from Thomas Jefferson to Mrs. Adams (Sept. 11, 1804), in 4 MEMOIRS, OF JEFFERSON, supra, at 26-27; Letter from Thomas Jefferson to W.H. Torrance (June 11, 1815), in 9 THE WRITINGS OF THOMAS JEFFERSON, supra, at 516, 517-18; Letter from Thomas Jefferson to Spencer Roane (Sept. 6, 1819), in 10 THE WRITINGS OF THOMAS JEFFERSON, supra, at 140-42; Letter from Thomas Jefferson to William Jarvis Short (Sept. 28, 1820), in THE WRITINGS OF THOMAS JEFFERSON, supra, at 160-61.
} 
without regard to what the others may have decided for themselves under a similar question."143

In essence, by recognizing judicial review in this limited form, Madison was simply adding courts to the process of public deliberation described above. The judiciary became an additional voice when it came to constitutional questions: another source of leadership for the community, and one more potential check in the system of popular constitutionalism built into our complex government. If a bill passed Congress and was signed by the President without protest from the states, it was still possible for the Supreme Court to raise a constitutional objection and ask the public to reconsider by wielding its power of review as what amounted to a judicial veto.

This much is straightforward, at least as a conceptual matter. Someone must have final authority to resolve constitutional conflicts, but in a system based on popular sovereignty that someone can never be the government or any part of it. Government agents, whether legislators, executives, or judges, are just that: agents. When it comes to the Constitution, they are the regulated, not the regulators. They must do their best to decide what the Constitution permits, forbids, or requires them to do, but final interpretive authority always rests with their actual superior, "the people themselves." Hence, when Madison, Jefferson, and their supporters proffered what later scholars have called "departmental" or "concurrent" or "coordinate" review, ${ }^{144}$ they were not advocating a process in which no one had final say. They were defending a system in which the people's different agents, including judges, could articulate their varied understandings of the Constitution in the ordinary course of business and, in effect, present these to a common superior for judgment. If constitutional conflicts arose, they would in the end be resolved the only way they could be resolved in a republican government: they would be decided by the people. As Virginia Senator Stevens Thomas Mason explained:

Though ... each department ought to discharge its proper duties free from the fear of the others, yet I have never believed that they ought to be independent of the nation itself.... All the departments of a popular Government

\footnotetext{
143 Letter from Thomas Jefferson to Spencer Roane (Sept. 6, 1819), in 10 THE WRITINGS OF THOMAS JEFFERSON, supra note 142, at 140, 142.

144 See ROBERT LOWRY CLINTON, MARbURY V. MADISON AND JUdICIAL REVIEW 24 (1989); SHANNON C. STIMSON, THE AMERICAN REVOLUTION IN THE LAW 100-104 (1990); Michael Stokes Paulsen, The Most Dangerous Branch: Executive Power To Say What the Law Is, 83 GEO. L.J. 217, 228-29 (1994).
} 
must depend, in some degree, on popular opinion. None can exist without the affections of the people, and if either be placed in such a situation as to be independent of the nation, it will soon lose that affection which is essential to its durable existence. ${ }^{145}$

Ideally, of course, disputing branches of government would achieve an accommodation on their own, though Jefferson once observed that "We have ... in more than one instance, seen the opinions of different departments in opposition to each other, \& no ill ensue."146 Still, accommodation by and among the branches was what all the checking and balancing that Madison had described in Federalist 51 was supposed to accomplish. And if no compromise was forthcoming, if different departments insisted on what Senator John Breckinridge of Kentucky called "[a] pertinacious adherence ... to their opinions", it was obvious who would decide. ${ }^{147}$ The issue would be answered, in Madison's words, by "the will of the community, to be collected in some mode to be provided by the constitution, or one dictated by the necessity of the case."148

This way of thinking about the role of courts supports a system of judicial review, but one with no notion or idea of judicial supremacy. That's hardly surprising given what we know of Madison's thinking. Assigning courts supremacy over constitutional interpretation would have been flatly anti-republican, because it would have deprived the community

145 Stevens Thomas Mason, Speech to Congress, in 11 ANNALS OF CONG., supra note 59, at 59. 146 MAYER, supra note 142, at 270. The quoted passage is from Jefferson's notes for his First Inaugural Address. He deleted the passage because, in context, it pertained to his plans to pardon those convicted under the Sedition Act, and this was a politically controversial step that Jefferson wanted to downplay in the interest of striking a conciliatory tone. See id. at 269; see also Letter from Thomas Jefferson to W.H. Torrance (June 11, 1815), in 9 THE WRITINGS OF THOMAS JEFFERSON, supra note 142, at 518.

147 "Although ... the courts may take upon them to give decisions which impeach the constitutionality of a law, and thereby, for a time, obstruct its operations," Breckinridge explained:

Yet I contend that such a law is not the less obligatory because the organ through which it is to be executed has refused its aid. A pertinacious adherence of both departments to their opinions, would soon bring the question to issue, in whom the sovereign power of legislation resided, and whose construction of the law-making power should prevail.

11 ANNALS OF CONG., supra note 59, at 179-80. By "bring the question to issue," Breckinridge means, of course that "pertinacious adherence" to conflicting views by different branches would force the public to decide.

148 James Madison, Speech to the House of Representatives on the President's Removal Power, (June 17, 1789), in 12 PAPERS OF MADISON, supra note 14, at 238. 
Valparaiso University Law Review, Vol. 41, No. 2 [2007], Art. 5

of final say over the meaning of their Constitution by giving it to a mere agent of the people-worse, an agent structured and designed to be as unaccountable as possible. And that is something Madison could never accept. The right of the people "to judge whether the [Constitution] has been dangerously violated," he wrote in 1800 , "must extend to violations by one delegated authority, as well as by another; by the judiciary, as well as by the executive, or the legislature."149

Yet review without supremacy is meaningful only if there is some way for the people to control judicial interpretations, just as they control interpretations of the political branches. Which raised an exceedingly awkward problem, for how are "the people" supposed to repudiate or overturn decisions of the courts on constitutional questions? When it came to Congress or the President or the political branches of the states, the forms of popular control were obvious. The same devices that created accountability were the tools by which the public registered its agreement or disagreement and ensured that constitutional disputes were resolved according to popular opinion, particularly as, over time, these devices fostered a general culture of responsiveness among elected representatives.

But courts were not accountable in these ways, and they had been selfconsciously constructed to be shielded from precisely these sorts of pressures. As noted above, ${ }^{150}$ this was to ensure fair decisions in ordinary cases of "private Right," and not because courts were expected to play the part of final arbiter of constitutional meaning. ${ }^{151}$ But whatever the reason, judicial independence was a fact, and it created a dilemma in defining the courts' role in a system of popular constitutionalism: how do we secure accountability for constitutional decisions when courts are independent and when, given their other responsibilities, we want them to remain so?

\footnotetext{
149 James Madison, Report on the Alien and Sedition Acts (Jan. 7, 1800), in MADISON: WRITINGS, supra note 14, at 608, 613 [hereinafter Madison, Report].

150 See supra notes 131-34 and accompanying text.

151 There was one commentator who tied judicial independence to judicial review: Alexander Hamilton argued in Federalist 78 that, in addition to its usual functions, judicial independence "is peculiarly essential in a limited constitution" because "the courts were designed to be an intermediate body between the people and the legislature, in order, among other things, to keep the latter within the limits assigned to their authority." THE FEDERALIST No. 78, at 524-25 (James Madison) (Jacob E. Cooke ed., 1961). Although Hamilton was defending only the modest form of review discussed in the text and had not yet pushed the argument to the point of judicial supremacy, he was nevertheless out ahead of everyone else in his reasoning, neither the first nor the last time this would be so. Of course, the importance of Federalist 78 is entirely retrospective. It played no role in Ratification, as it was published too late and had too limited a circulation to have influence, and no one else at the time made a similar argument. See KRAMER, THE PEOPLE THEMSELVES, supra note 1, at 80-81; supra note 133.
} 
The opportunity to overturn judicial decisions by constitutional amendment was not an answer, any more than it would have been an answer to action by the political branches. No one had ever doubted the people's authority to create new constitutional law. But as we have seen, the accompanying power to declare the meaning of the existing constitution had also always been held by the community, and it remained central to the very idea of republicanism. The unquestioned existence of popular authority to make constitutional law thus did not and could not justify denying popular authority to control its interpretation, something that would be true, I think, even had amending the Constitution not become so difficult as to make its possibility meaningless as a practical matter.

Nor did Americans write provisions for amendment into their constitutions with any idea that, in doing so, they were supplanting popular authority to interpret. Rather, as explained in The People Themselves, 152 formal amendment processes were developed to address problems that could not be solved by interpretation. Americans were aware that their constitutions incorporated numerous untried innovations, and for all their eagerness and enthusiasm, they expected some of these to fail. Problems that arose because of ambiguity or uncertainty in the text could be resolved by a Madisonian process of public deliberation and interpretation - the same sort of process that had resolved constitutional conflicts throughout British and colonial history and that Madison would later say had settled the constitutionality of a federally-chartered bank several years before John Marshall addressed the issue. ${ }^{153}$ But what about constitutional provisions that were unambiguous, but turned out to be mistakes? What about provisions that worked at the beginning, but became obsolete or dysfunctional over time? Popular constitutionalism was not a blank check for the public to ignore the law it had made. If the Constitution was clear, it had to be changed, not interpreted.

Yet traditional popular means for changing a constitution were difficult at best, and experience taught that most often change was accompanied by violence and civil unrest. So Americans chose to address the problem by creating something new, in George Mason's words, "an easy, regular and Constitutional way" to make revisions. ${ }^{154}$ The amendment device could also be used to cure ambiguities, but this was neither its motivation nor its

\footnotetext{
152 KRAMER, THE PEOPLE THEMSELVES, supra note 1 , at 51-54.

153 See McCulloch v. Maryland, 17 U.S. (4 Wheat.) 316 (1819); James Madison, Veto Message (Jan. 30, 1815), in 1 A COMPILATION OF THE MESSAGES AND PAPERS OF THE PRESIDENTS 555 (1900).

154 Notes of James Madison (June 6, 1787), reprinted in 1 FARRAND, supra note 14, at 202-03 (remarks of George Mason).
} 
Valparaiso University Law Review, Vol. 41, N0. 2 [2007], Art. 5

main purpose (which may be why supporters of judicial authority did not at the time rely on its availability for support). The power to amend, in any event, was situated in a legal and intellectual framework in which interpretive authority remained where it had always been: with the people at large.

Which brings us back to the same quandary: if judges are not elected and their salaries are protected, and we give them power to obstruct actions by the other branches on constitutional grounds, how do we retain popular control over the Constitution? At this point, I want to digress briefly to consider how the major powers of modern Europe have handled the problem. Germany, France, Italy, and Spain (not to mention Russia and the nations of Eastern Europe) have all adopted new constitutions since World War II. As such, they were able to design their governments with our experience in mind, and it has not been missed that all chose for the first time to embrace strong doctrines of judicial review. Less noticed is how these nations structured their judiciaries differently from ours precisely to enable their courts to act while preserving an adequate degree of popular control.

To begin with, the nations of Western Europe delegated constitutional adjudication to special courts, which were set apart from the regular legal system in recognition that the constitution is not just another species of ordinary law and that constitutional litigation is not just another species of litigation. 155 The sole function of these courts is to review constitutional questions. They do not address other matters or issue judgments over whole cases, thus disentangling constitutional review from more conventional legal matters. By this means, independence in constitutional cases could be (and has been) structured and balanced differently than in ordinary cases, enabling the Europeans to take the inherent political nature of constitutional law into account without compromising the need to exclude politics from ordinary litigation.

Given the high political station occupied by constitutional courts, various provisions were then made to ensure an appropriate level of political responsiveness while still securing the courts' ability to act as an independent counterweight. Once on the bench, the judges are independent. But unlike in other European courts, appointment is political rather than bureaucratic. More important, getting appointed typically

155 See Louis Favoreu, Constitutional Review in Europe, in CONSTITUTIONALISM AND RIGHTS: THE INFLUENCE OF THE UNITED STATES CONSTITUTION ABROAD, 38, 40-59 (Louis Henkin \& Albert J. Rosenthal eds., 1990); Hans Kelsen, Judicial Review of Legislation: A Comparative Study of the Austrian and the American Constitution, 4 J. POL. 183 (1942). 
requires a supermajority in one or both houses of the legislature, thus guaranteeing that constitutional courts have a mainstream ideology, and the judges serve terms that are limited and staggered to ensure that this remains so through regular turnover. ${ }^{156}$ Finally, the constitutions themselves were made more easily amendable than ours.

The combined effect of these structural innovations has been to relieve the pressure a doctrine of supremacy creates, by reducing the likelihood of serious breaches between the constitutional court and the other branches of government and by making political correctives easier to implement when breaches occur. Partly as a result, constitutional courts in Europe have managed successfully to mimic or even exceed American activism without the same controversy, though recent developments suggest that European judges, too, may be approaching the limits of their authority. ${ }^{157}$

Structural precautions like these are not found in the United States Constitution because when our Founding Fathers wrote it no one had yet imagined anything even remotely like modern judicial supremacy. Judicial review was first conceived in this country in the context of ordinary litigation, and it matured as an aspect of the normal legal system, intermingling constitutional decisions with other legal questions and conflating constitutional and ordinary law. This meant, among other things, that the robust protection given American judges in ordinary cases, where popular control can be maintained through regular politics, ended up similarly protecting judges from popular control in constitutional cases. As judicial power expanded and its potential and political importance became clear, supporters and defenders of popular constitutionalism discovered a need to compensate for this mistake in our constitutional design. With no models or prior experience to work from, they and their successors handled the problem of courts as they handled so many other unanticipated problems: by innovating and jerry-rigging a system of political solutions on the fly, as problems arose.

156 See the country-by-country surveys in VICKI C. JACKSON \& MARK TUSHNET, COMPARATIVE Constitutional LaW 489-91 (1999); Alec StOne SWEet, Constitutional Adjudication and Parliamentary Democracy, in GOVERNING WITH JUdGES: CONSTITUTIONAL POLITICS IN EUROPE tbl.2.3 (2000).

157 The most obvious example is the decision of the Federal Constitutional Court of Germany concerning the display of a crucifix in the classroom, 93 BVerfGE 1 (1995), which Donald Kommers reports has "tarnished the court's reputation in the eyes of many Germans and raised questions ... about the legitimacy of judicial review," questions that are common in the United States but until now have been "a rare occurrence in Germany." DONALD KOMMERS, THE CONSTITUTIONAL JURISPRUDENCE OF THE FEDERAL REPUBLIC OF GERMANY xiv (2d ed. 1997). Similar concerns are beginning to percolate in other countries as well. 
Valparaiso University Law Review, Vol. 41, No. 2 [2007], Art. 5

The solutions they crafted are familiar. ${ }^{158}$ Thomas Jefferson (with full support from his Secretary of State James Madison) abolished a lower court, revised Supreme Court procedures, threatened to ignore the Court's mandates, and briefly pursued a strategy of impeaching judges. Andrew Jackson followed Jefferson in threatening to ignore judgments, while Lincoln actually did so (and on more than one occasion). Congresses before and after the Civil War manipulated the Court's size, played with its budget, and stripped it of jurisdiction in controversial areas. Theodore Roosevelt advocated recalling both errant judges and faulty opinions, while his cousin Franklin made a famously brazen effort to pack the bench (one that would almost certainly have succeeded had the Court not backed down first).

I will not undertake in this Lecture to examine how these or similar devices might work today. As the strong reactions of many reviewers of The People Themselves make clear, this is a controversial subject, and it requires more depth and detail than the present occasion allows. Nor do I mean to reduce popular constitutionalism to these few blunt tools. As others have pointed out, there are multiple avenues by which popular will finds its expression in courts. ${ }^{159}$ There do, however, need to be mechanisms to make clear and to operationalize where ultimate authority lies. I continue to believe that we need these devices, or something that can serve their function, if we are to restore the robust sense of popular constitutionalism on which this nation was founded and that remains its best and most distinctive contribution to government and democratic theory. All this, however, is the subject for a second book. For now, then, let me close with a few observations meant to lay some of the groundwork for further investigation.

What I have mainly attempted to accomplish here is to recover Madison's theory of deliberative democracy and restore to modern understanding its fundamental popular and democratic character. That theory includes a role for courts, but a modest one, consistent with Madison's lifelong commitment to securing the community's active and actual control over the interpretation (as well as the making) of

\footnotetext{
158 For a useful survey, see CHARLES GEYH, WHEN COURTS AND CONGRESS COLLIDE (2006). 159 See Robert C. Post, Foreword: Fashioning the Legal Constitution: Culture, Courts, and Law, 117 HARV. L. REV. 4 (2003); Robert C. Post \& Reva Siegel, Legislative Constitutionalism and Section Five Power: Policentric Interpretations of the Family Medical Leave Act, 112 YALE L.J. 1943 (2003); Reva Siegel, Constitutional Culture, Social Movement Conflict, and Constitutional Change: The Case of the De Facto ERA, 94 CAL. L. REV. 1323 (2006).
} 
constitutional law. Madison sought to achieve this control through a system of "departmentalism," in which different departments of government were first made dependent on the people and interdependent on each other, and then given authority to pursue and act on their own best understanding of the Constitution. By this means, Madison sought to generate what amounted to a competition of understandings among political officials that, by forcing the leadership class to appeal to the community for support, would simultaneously inform public opinion and secure its sovereignty.

There is room for a doctrine of judicial review in Madison's approach, but not for anything resembling judicial supremacy. The judiciary, too, must be subject to community discipline via popular reactions to challenges from the other departments, which must then in turn possess viable means to gainsay judicial interpretations. In the past, this meant political pressure backed ultimately by the possibility of such things as ignoring mandates, budget cutting, jurisdiction stripping, court packing, and the like. And for myself, I would prefer these sorts of devices to nothing. But whatever the appropriate means might be, the opportunity to ask the Justices to reverse themselves, to make occasional appointments, and to amend the Constitution are not enough.

Departmentalism is not the same as anarchy. It does not mean, for instance, that every government official or employee is free to act according to his or her own understanding of the Constitution. Quite the contrary, a departmental approach works only if there is enforced discipline within the respective branches. The President must be able to remove cabinet officers or other subordinates who refuse to follow executive policy, just as lower courts must respect and follow Supreme Court precedents whatever a judge's individual views. Departmentalism is a process for channeling different positions to the public through functional agencies, not a free for all.

Even this more restrained understanding seems to baffle modern commentators, who see departmentalism as a system in which no one has final say and so a formula for continual conflict and confusion. ${ }^{160}$ From a

160 I discussed different commentators' puzzlement with departmentalism and explained how Madison's version of it differed in KRAMER, THE PEOPLE THEMSELVES, supra note 1, at 10607. Some reviewers of the book somehow missed this discussion and simply repeated the same criticisms of the theory. See Larry Alexander \& Lawrence B. Solum, Popular? Constitutionalism?, 118 HARV. L. REV. 1594, 1609-15 (2005) (book review). 
Valparaiso University Law Review, Vol. 41, N0. 2 [2007], Art. 5

theoretical or conceptual standpoint, this reaction reveals the extent to which we have lost touch with the very idea of popular constitutionalism. For what underlies the commentators' skepticism is an unstated assumption not just that someone must have final authority to resolve routine constitutional conflicts, but that this someone can only be a governmental agency. It misses the central principle of popular constitutionalism, which is that final interpretive authority can and must rest with the people themselves.

From a practical standpoint, equating departmentalism with chaos misses the extent to which our system truly is responsive. On the one hand, different branches of government may well disagree for a time and, as Jefferson observed, "no ill ensue."161 In fact, this happens constantly even with judicial supremacy, as the Supreme Court often takes years to get around to addressing issues and just as often fails to settle them clearly. On the other hand, once public sentiment has begun to swing decisively in a particular direction, the political branches of government will all invariably follow, whatever the personal preferences of their members. (Lest you doubt it, consider the effort to remove President Clinton. As determined and disciplined as the Republicans were, and American political parties have seldom been this determined or disciplined, public antipathy toward impeachment kept them from even coming close to convicting. Other examples abound, too.) On any issue that captures the public's attention, where the majority goes is where government policy will go. Madison's genius was in conceptualizing and helping to create a realistic process for making this fact operational by "contriving the interior structure of the government" to foster debate, educate the public, register its responses, and translate these responses into action. It may sometimes be slow and not very pretty, but it works. ${ }^{162}$

One way in which the process may seem ugly is in how little is specified. There are no easy rules of recognition to identify how a constitutional issue arises, much less how it gets resolved. There are not

\footnotetext{
161 See MAYER, supra note 142, at 270.

162 THE FEDERALIST NO. 51, supra note 17, at 320 . And to the extent it no longer works, the answer must be to fix it, not to surrender power to the least democratic institution in our government. No doubt politics today is broken in a number of respects. The belief that elections would sift out "the purest and noblest characters" in society was unrealistic even in Madison's day, see Madison, Vices of the Political System, supra note 99, at 357, but political leadership has probably never been worse than now. The sad state of our media is a problem, as is the dissolution of functional political parties and much of the rest of civil society. But these problems are addressable, and it's our responsibility to address them. If we do, we will not need to give the Supreme Court so much authority; if we do not, we might need to give up on the idea of functional democracy more broadly.
} 
even clear rules about how one knows if something is a constitutional issue. Instead, such matters are left to the free play of interbranch and intergovernmental politics. Actors in any institution can try to turn something into a constitutional question, and the only measure of their success or failure is how other political actors and the public respond. Nor is the ability to initiate a debate limited to formal institutions of government. Social movements, different parts of civil society, even individuals may equally launch a campaign based on a novel reading of the Constitution, with the test of validity being only whether they can persuade enough others to embrace or adopt their position. In reality, of course, the process is nowhere near as open as this might suggest. Not every crazy idea stands an equal chance of success, because political culture and tradition naturally limit what kinds of arguments that have appeal in public discourse, which ensures a great deal of consistency over time. Change still tends to be incremental and continuous.

The system remains departmental in that, in the final analysis, the proof of who has prevailed will necessarily be seen in what public agents do (or stop doing). There will be some innovation in government - a decision, an administrative practice, a law, a new structure - that either succeeds or fails, and its success or failure marks a conflict's resolution. But how and when that resolution takes place, or by which institution it is determined, can change and may be impossible to predict. Different branches or different levels of government can hold sway at different times, and power moves constantly about. This is the sense in which popular constitutionalism is like politics. The public arguments may be different, may be about the meaning of text or precedent and not just about the right thing to do, but the process by which these arguments are decided is as undefined and unspecified as anything else that gets decided in the hurly burly of politics and public debate.

That can be disconcerting, especially to lawyers, who like identifiable rules of procedure and recognition and have gotten used to thinking of the Constitution as a matter for ordinary judicial process. It should not be. In the end, the view that prevails (and I mean this with respect to both whether something is a constitutional issue and how it should be decided) is the view that always prevails, which is to say the view of whoever we decide has final interpretive authority. The difference is that, unlike judicial supremacy, which vests that authority in the Supreme Court, a system of popular constitutionalism vests it in "the people themselves."

Even this is an exaggeration. On most constitutional issues, no one inside or outside government will be able to rouse sufficient public ire to 
Valparaiso University Law Review, Vol. 41, N 0.2 [2007], Art. 5

752

undo the actions of whichever branch speaks last. And as Madison often observed, as a practical matter this tends to be the judiciary. ${ }^{163}$ We have seen his point demonstrated throughout history, just as we see it today. Efforts to stir opposition to the Supreme Court may be frequent, and extreme views certainly seem to appear with regularity. Such is the effect of free speech. But the anxiety bordering on panic that this opposition arouses is unnecessary. Because politicians who choose to take on the Court must still be able to rally enough support to get action, and that turns out to be extremely difficult. Just ask Franklin Roosevelt. Or Tom DeLay. Even Jefferson hesitated before confronting the Marshall Court, though eventually the Federalist bench pushed him too far. ${ }^{164}$ It takes a proverbial long train of abuses - a persistent course of provocative and unpopular action by the Justices, usually over a sustained period-before a large enough majority of the public will allow responsive measures, and even then an enormous amount of political energy must be expended to produce actual legislative or executive countermeasures. The American people, it turns out, are fully capable of grasping the benefits of having a strong judiciary, even when they disagree with particular decisions. And if they forget, there are always political leaders out there to remind them. It is no coincidence that only very popular presidents have managed successfully to confront the Court, and only after extraordinary provocation. The judiciary is a quite robust political institution, more like an 800-pound gorilla than the 90-pound weakling Hamilton fretted about in Federalist 78. But its strength or weakness should be a product of its ability to make decisions that persuade the public, unaided by an artificial doctrine designed to disarm the other branches and lull the public into passivity.

Put another way, the judiciary does not need supremacy to play its role in a system of separation of powers. Our history makes this abundantly clear, for the Court has been an active and important institution from early on, whereas the idea of supremacy has found broad acceptance only in the past generation or two. As social scientists have long understood, a reasonably prudent Court can establish and sustain a high degree of

163 Madison recognized this point on numerous occasions during more than forty years of thinking about courts. See, e.g., Letter from James Madison to Mr. (1834), in 4 LETTERS OF MADISON, supra note 93, at 349-50; Madison, Observations of Jefferson's Draft, supra note 14, at 315; Madison, Report, supra note 149, at 613-14.

164 See Noble E. CunNingham, THE JeFFERSONIAN Republicans IN POWER: PaRTy OPERATIONS, 1801-1809, at 12-70 (1963); RICHARD E. ELLIS, THE JEFFERSONIAN CRISIS: COURTS AND POLITICS IN THE YOUNG RePUBlic 44 (1971); KRAMER, THE PEOPLE THEMSELVES, supra note 1, at 117-19; DUMAS MALONE, JEFFERSON THE PRESIDENT: FIRST TERM, 1801-1805, at 17-28, 69-89 (1970); James O'Fallon, Marbury, 44 STAN. L. REV. 219, 238, 242 (1992). 
authority even without formal support from a doctrine of supremacy. ${ }^{165}$ The reasons were identified by Madison as far back as 1834. Even within a departmental framework, Madison speculated:

[T] he Judicial department most familiarizes itself to the public attention as the expositor, by the order of its functions in relation to the other departments; and attracts most the public confidence by the composition of the tribunal.... [T] he public deference to and confidence in the judgment of the body are peculiarly inspired by the qualities implied in its members; by the gravity and deliberation of their proceedings; and by the advantage their plurality gives them over the unity of the Executive department, and their fewness over the multitudinous composition of the Legislative department. ${ }^{166}$

It does not follow that nothing is at stake in the choice between a system of judicial supremacy and one based on departmental construction. In the latter system, the authority of judicial decisions formally and explicitly depends on reactions from the other branches and, through them, from the public. This, in turn, can make an enormous difference in how the Justices behave. There may be political obstacles to punishing the Court that make it possible, even without judicial supremacy, for the Justices to have their way most of the time. But the obstacles are smaller: smaller by precisely the weight conferred on Supreme Court decisions by the doctrine of judicial supremacy, which, if that doctrine is widely accepted, can be considerable.

165 See David Adamny \& Joel Grossman, Support for the Supreme Court as a National Policymaker, 5 LAW \& POL'Y. Q. 405 (1983); Gregory A. Caldeira, Neither the Purse nor the Sword: The Dynamics of Public Confidence in the United States Supreme Court, 80 AM. POL. SCI. REV. 1209 (1986); Gregory A. Caldeira \& James L. Gibson, The Etiology of Public Support for the Supreme Court, 36 AM. J. POL. SCI. 635, 636 (1992); James L. Gibson, Gregory A. Caldeira \& Vanessa A. Baird, On the Legitimacy of High National Courts, 92 AM. POL. SCI. REV. 343, 356 (1998); Roger Handberg, Public Opinion and the United States Supreme Court, 1935-1981, 59 INT'L SOC. SCI. REV. 3 (1984); Joseph Tanenhaus \& Walter F. Murphy, Patterns of Public Support for the Supreme Court: A Panel Study, 43 J. POL. 24 (1981).

166 Letter from James Madison to Mr. (1834), in 4 LETTERS OF MADISON, supra note 93, at 349-50. See James L. Gibson, Gregory A. Caldeira \& Lester Kenyatta Spence, The Supreme Court and the U.S. Presidential Election of 2000: Wounds, Self-Inflicted or Otherwise?, 33 BRIT. J. POL. SCI. 535 (2003).

When courts become salient, people become exposed to the symbolic trappings of judicial power-'the marble temple, the high bench, the purple curtain, the black robes'... . Thus, the effect of displeasure with a particular court decision may be muted by contact with these legitimating

Id. symbols. To know courts is indeed to love them .... 
The result of removing this weight is not more conflict. Indeed, a great irony of making clear that we can and should discipline an overreaching Court is that it will then almost never be necessary to do so. Rather than more or constant conflict, we will instead see a different equilibrium emerge, as a risk-averse and potentially vulnerable Court adjusts its behavior to greater sensitivity on the part of political leadership in the other branches. The practical likelihood of being overturned may be small, but the sense of responsibility thus engendered, together with a natural desire to avoid controversy and protect the institution of the Court, would inevitably change the dynamics of decision-making. It is this, in fact, that explains how the Supreme Court has historically husbanded its authority even without judicial supremacy, as well as why crises occurred only when an overconfident Court claiming to be supreme paid too little mind to the public's view of things. ${ }^{167}$

At the end of Federalist 10, Madison exults in what he has accomplished. By enlarging the sphere of the republic, he boasts, "we behold a Republican remedy for the diseases most incident to Republican Government."168 Political theorists and constitutional scholars have focused too much on Madison's concern for the diseases incident to republican government without paying adequate attention to the first "republican" in that sentence. Certainly Madison was concerned about the dangers of popular government and "the excess of democracy."169 But not just any remedy would do. The remedy had to be a republican remedy, a remedy consistent with the popular constitutionalism that was the fundamental premise of the Revolution and of Madison's own life and philosophy. And he found his remedy, too, one that is, or rather could be made, as relevant and useful today as it was at our nation's inception.

\footnotetext{
167 John Ferejohn \& Larry D. Kramer, Independent Judges, Dependent Judiciary: Institutionalizing Judicial Review, 77 N.Y.U. L. REV. 962 (2002).

168 THE FEDERALIST NO. 10, supra note 10, at 65.

169 Madison's Notes (May 31, 1787), in 1 FARRAND, supra note 14, at 48 (comments of Elbridge Gerry). Modern commentators often misquote Gerry's notorious comment, turning it into concern for "the excesses of democracy," thus giving the phrase a quite different connotation that reveals modern anxieties more than those of the Founders. For an example, though the mistake is really quite common, see DANIEL A. FARBER \& SUZANNA SHERRY, A HISTORY OF THE AMERICAN CONSTITUTION 18 (2d ed. 2005).
} 